\title{
Seismicity and structure of the Indian subcontinent
}

\author{
1. Formerly: Geological Survey of India, Kolkata; presently: National Institute of Technology, Agartala, India \\ 2. CSIR-National Geophysical Research Institute, Hyderabad, India
}

(Received : 27/09/2019; Revised accepted : 15/10/2019)

https://doi.org/10.18814/epiiugs/2020/020043

We present a short review on the seismicity and crustmantle structure of the Indian subcontinent highlighting the major findings of the work done during the last few decades. Seismicity pattern and seismic power-law characteristics and the velocity structures studied by different techniques (seismic tomography, receiver function etc.) for various tectonic zones of the Indian subcontinent are summarized. In addition, some results on seismic anisotropy, seismic attenuation and ambient noise analyses are abridged. The results though provide some insight into the seismicity, triggered earthquakes, crust - mantle velocity and lithospheric structures for the continental shield region, oceanic intrapale, collision and subduction zones of the Indian subcontinent, highresolution sub-surface images need to be studied using high quality denser seismological network data with integrated multi-geophysical, satellite and other imagery data in future study.

\section{Seismicity}

The Indian subcontinent is highly vulnerable to devastating earthquakes, mainly because of the collision tectonics of the gently dipping / subducting Indian plate beneath Asia at a higher rate of 47 $\mathrm{mm} /$ year (Bendick et al., 2002). India has a varying degree of seismicity or regions ranging from the Stable Continental Region (SCR) in the south with strong ( $\mathrm{M}>6.0$ ) earthquakes to the Himalayas, $\mathrm{NE}$ India, Indo-Burma and Indian Ocean regions with large (M>7.0), great $(M>8.0)$ and mega $(M w>9.0)$ earthquakes. Seismicity in India is categorized into four zones [IS 1893 (Part 1) 2002] (Fig. 1a). The four zones are Zone II: seismically less active, Zone III: moderately active, Zone IV: highly active, while the Zone V represents highest seismicity. Seismicity is one of the major components of earthquake hazard assessment of a region that can be described in terms of several power laws. These parameters are the b-value describing the frequency-magnitude relation (Gutenberg and Richter, 1954), Omori's p-value describing seismicity decay rate (Utsu, 1961), fractal dimension describing active fault distribution pattern, and static and dynamic stresses for triggering earthquakes.

In last two decades, seven devastating earthquakes such as the
1991 Uttarkashi ( $m_{b}$ 6.6), the 1999 Chamoli ( $m_{b}$ 6.3), the 2005 Kashmir ( $M_{w}$ 7.8), the 2011 Sikkim (Mw 6.9) and the 2015 Nepal ( $M_{w}$ 7.8), (interplate) earthquakes along the Himalaya, the 2016 Imphal ( $M_{w}$ 6.7) earthquake in the Indo-Burma ranges, and the 1993 Killari $\left(m_{b} 6.3\right)$, the 1997 Jabalpur $\left(m_{b} 6.0\right)$ and the 2001 Bhuj $\left(M_{w}\right.$ 7.7) (intraplate) earthquakes in peninsular India, and the 2004 megathrust Sumatra-Andaman ( $M_{w}$ 9.3) earthquake in the AndamanSumatra subduction zone caused severe damages and large casualties in different parts of India and its neighboring regions. A general seismicity map of the region is shown in Fig. 1b. The major earthquakes that occurred along the Himalayan plate boundary along with their focal mechanisms and other seismo-tectonic features are shown in Fig. 1c. Rajendran et al. (2017) provide an excellent review of seismotectonics of all major Himalayan earthquakes; readers are referred to this work for details. As an example of the recent plate boundary earthquake in this zone, we briefly outline here the overall seismo-tectonic features of the $2015 \mathrm{Nepal}$ earthquake (Fig. 1c). Both the 2015 main shock $\left(M_{w} 7.8\right)$ and the largest aftershock $\left(M_{w} 7.3\right)$ occurred on the MHT, with the main shock triggered by the structural heterogeneity in the plate interface (Zhao et al., 2011). Subhadra et al. (2018) studied the seismogenesis of the crust based on seismicity and fractal analyses of the 2015 aftershock sequence. The detailed seismo-tectonic features of this event can be found in Hayes et al. (2015) and references therein.

\section{Instrumentally recorded tectonic earthquakes}

The 1897 great Shillong plateau earthquake $\left(M_{w} 8.1\right)$ in NE India region is the first instrumentally recorded Indian earthquake that was registered outside India by a few global seismic stations. After this great event, the first Indian seismological observatory was established in Alipore (Kolkata) in 1899 under auspices of the India Meteorological Department (IMD) (Kayal, 2008). Since then the national seismological network is developed; today it consists of some 115 broadband seismic observatories including some cluster-networks in NE India and in different segments of the Himalayas. In addition to these, a cluster of some 21 broadband stations is in operation in Koyna -Warna region and a cluster of some 50 broadband and 50 strong-motion stations is in operation in Gujarat state under the auspices of the Institute of Seismological Research (ISR), a newly established Institute in 2006. With the upgraded national network, earthquakes down to magnitude $\mathrm{M}_{\mathrm{w}} 3.5$ are fairly well located, and down to $M_{w} 2.0$ by the cluster networks. Recently, the Ministry of Earth Sciences (MoES) established the National Centre for 
Seismology (NCS), centre of excellence in Seismology in 2014. The NCS is now the custodian of seismological data of India including tectonic and induced/triggered earthquakes and aftershock sequences of strong and large earthquakes. A seismicity map of India and adjoining region with earthquakes $M_{w} \geq 5.0$ for the period 19902012 is presented in Fig 1b.

India has experienced several large and great earthquakes, since the 1897 great Shillong event, which are instrumentally recorded by the national seismological observatories. These are the 1905 Kangra earthquake $\left(M_{w} 7.8\right)$ in the western Himalaya, the 1934 Bihar -Nepal earthquake $\left(M_{w}\right.$ 8.2) in the foothills of central Himalaya and the 1950 great Assam earthquake in the eastern syntaxis zone of the Himalaya (Kayal, 2008). However, comprehensive aftershock studies using temporary networks are carried out for the recent damaging earthquakes since 1991. These significant earthquakes are the 1991 Uttarkashi ( $M_{w}$ 6.3) and 1999 Chamoli ( $M_{w}$ 6.3) earthquakes in the western Himalaya, the 1993 Latur $\left(M_{w} 6.3\right)$, the 1997 Jabalpur $\left(M_{w}\right.$ 6.0) and the 2001 Bhuj ( $M_{w}$ 7.7) earthquakes in peninsular India, the 2002 Andaman ( $\left.M_{w} 6.5\right)$ and the 2004 Sumatra $\left(M_{w}\right.$ 9.3) earthquakes in the subducting Indian oceanic plate, the 2005 Kashmir ( $\left.M_{w} 7.6\right)$, the 2009 Bhutan ( $M_{w}$ 6.3) and the 2011 Sikkim ( $M_{w}$ 6.9) earthquakes in different segments of the Himalayas and the 2016 Manipur $\left(\mathrm{M}_{\mathrm{w}}\right.$ 6.7) earthquake in NE India region (e,g, Kayal 2008, Kayal et al., 2010; Rao et al., 2015; Singh et al., 2017 and references therein). Seismotectonics of the main shocks and aftershock sequences of the above strong / large earthquakes are well studied, that shed fair

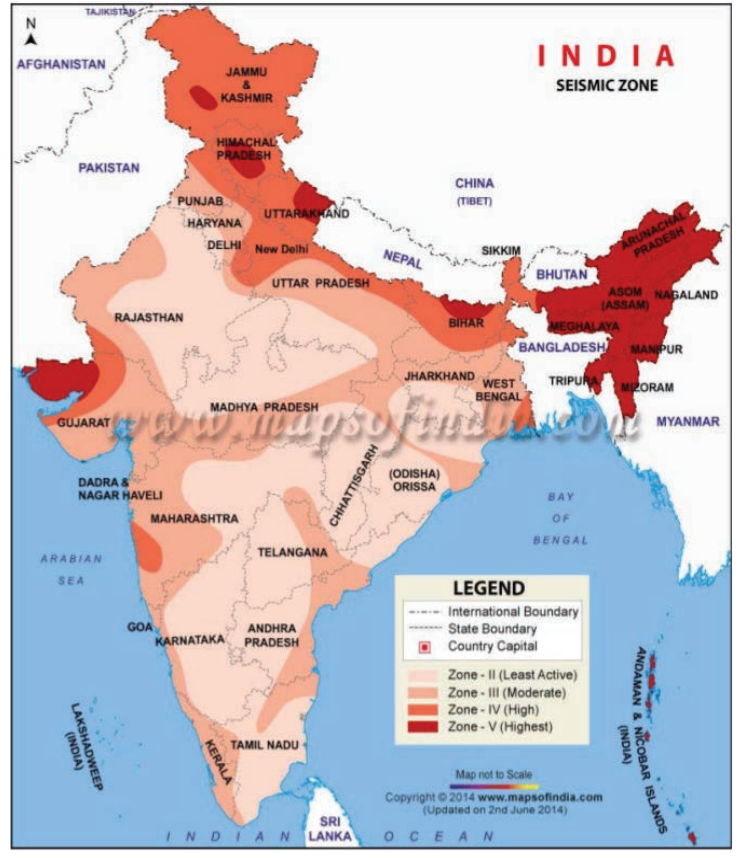

(a)

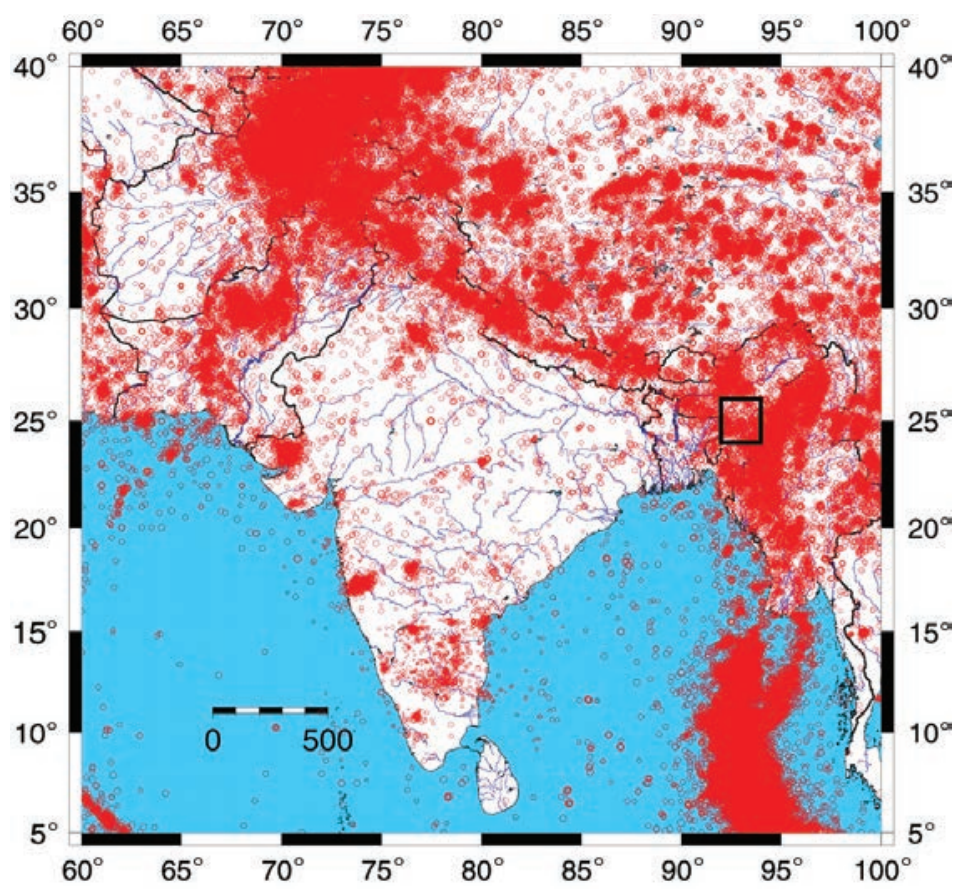

(b)
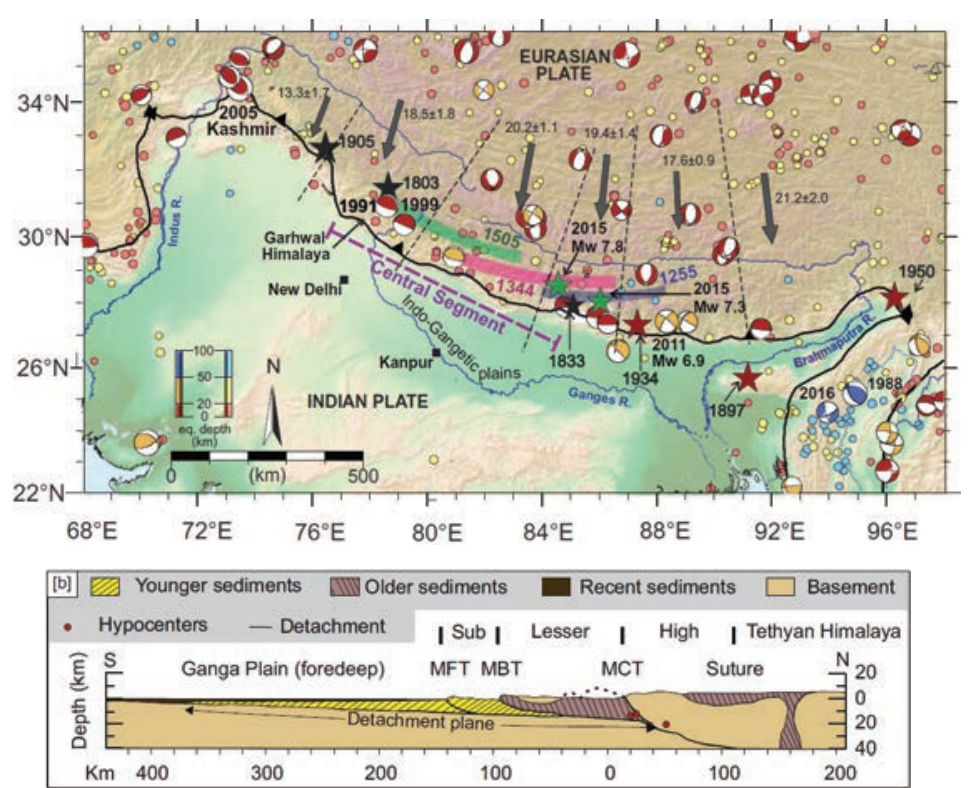

(c)
Figure 1. (a) Seismic zoning map of India (BIS, 2002). (b) Seismicity $\left(M_{w}>5\right)$ during the period 1990-2012 (USGS catalog) (after Serpetsidaki et al., 2013); the rectangular area represents lower Assam of the northeast India region. (c) Upper panel: Background seismicity showing the major earthquakes along the Himalayas, including the recent 2011 Sikkim and 2015 Nepal earthquakes (after Rajendran et al., 2017). Seismo-tectonic features are marked. Beach balls represent the focal mechanisms of the earthquakes. Arrows mark the GPS convergence rates in $\mathrm{mm} / \mathrm{yr}$ (Stevens and Avouac, 2015). Lower panel: Cross-section of the Himalayan thrust system along the $N$-S profile through central Himalaya. The circles show the source zones of the major events. Seismo-tectonic features of the region are shown. Major faults are: MFT: Main Frontal Thrust, MBT: Main Boundary Thrust, MCT: Main Central Thrust, and MHT: Main Himalayan Thrust (i.e. Detachment plane). 
understanding of seismic processes of these events in different tectonic domains of India.

The recently increased intraplate seismicity related to the April 11, 2012 earthquakes, $M_{w} 8.6$ and $M_{w} 8.2$, in Northern Wharton Basin and the May 21, 2014 Bay of Bengal $\left(M_{w}\right.$ 6.1) earthquake of the Indian Ocean indicates continuing deformation within the oceanic intra-plate (Andrade and Rajendran 2014; Mallick and Rajendran 2016). The enhanced seismicity in the Northern Wharton Basin in Indian Ocean since 2012 earthquakes $\left(M_{w} 8.6\right.$ and $M_{w}$ 8.2) are attributed to the stress transfer from the 2004 mega thrust earthquake $\left(M_{w}\right.$ 9.3) at the Sumatra-Andaman subduction zone (Andrade and Rajendran (2014).

\section{Triggered earthquakes}

The Koyna-Warna region in western India, a well-documented site for reservoir triggered seismicity (RTS), experienced some 15 earthquakes $M_{w} \geq 5$.0, including the 1967 largest reservoir triggered earthquake ( $M_{w}$ 6.3). Since then several hundred thousand smaller $\left(M_{w} \geq 1.0\right)$ earthquakes are recorded. Gupta et al. (2007) critically examined the seismicity pattern and reported that before a medium magnitude $\left(\mathrm{M}_{\mathrm{w}}>4.0\right)$ earthquake, nucleation of foreshock-cluster of smaller events is observed for 100-400 hours, and forecast of such medium magnitude earthquake is possible in such well monitored small reservoir area of 20x30 sq $\mathrm{km}$. For precise locations of the triggered events, a network of eight borehole seismometers are deployed at depths 1134-1522 m below the Deccan basalt cover along with the existing network of 21 broadband surface seismometers. The network is designed and operated by the National Geophysical Research Institute (NGRI), and the seismicity down to magnitude Mw 0.5 are monitored (Shashidhar et al., 2016). Recently, Gupta (2018) reviewed the findings of multi-geophysical and seismological investigations carried out during the last 50 years to understand common characteristics of the RTS events, role of reservoirs in triggering the earthquakes and their relation with water level changes. Arora et al. (2018), on the other hand, presented a new model of basement faulting based on the analysis of lineaments derived from imagery and airborne light detection and ranging (LIDAR) data in the Koyna-Warna region. Their model suggests that the presence of fluid-filled fractured basement rocks fairly explain the increased pore fluid pressure and triggered earthquakes.

The large digital seismic data recorded over few decades in the Koyna-Warna region are analyzed to image 3D crustal velocity structure down to $10 \mathrm{~km}$ depth (Shashidhar et al., 2011). Further, the power- law relations of seismicity are used to examine precursor anomalies for earthquakes $M_{w}>4.5$ based on temporal changes in band D- values (Mandal et al., 2005). Singh et al. (2008) interpreted their correlation in terms of reservoir loading with a steady state stress distribution. Telesca (2011) analyzed the Koyna catalog to explain the time-dependent clustering of epicenters based on the value of the scaling exponent $\alpha$, estimated by using the Allan Factor method. The variation in scaling exponent is correlated with the enhanced preand co-seismic activities related to the occurrence of larger events in the sequence. Dev and Nagarajan (2017), on the other hand, presented probabilistic seismic hazard for the Koyna region. Their results show recurrence interval of earthquakes of $M_{w}>5.5$ is around $100 \pm 10$ years. The estimated peak ground acceleration (PGA) for $10 \%$ probability of exceedance in 50 years (i.e. 500 years of return period) is greater than $21 \% \mathrm{~g}$ within $\sim 30 \mathrm{~km}$ radius between the Koyna and Warna reservoirs.

Clustering of earthquakes in space and time can either be attributed to triggering caused by previous earthquakes / remote triggering or to changes in underlying physical process. For example, occurrence of aftershocks following the large main shock is an example of earthquake triggering, while occurrence of swarms of smaller earthquakes without any large event points to the later process, such as physical changes caused by fluid migration. Bansal et al. (2016) investigated distinct regions of remote triggering in south/southeast Asia following the $2012 \mathrm{M}_{\mathrm{w}}$ 8.6 Indian Ocean earthquake. Their results show evidence of triggered tectonic tremors beneath the Java Island and the Sulabes Island in eastern Indonesia and triggered earthquakes in Vietnam, where tremors occurred during the passage of large amplitude Rayleigh waves of the Indian Ocean main shock and other large distant earthquakes. They, however, found no evidence of triggered tremors along the Sumatra subduction zone or along the eastern Himalaya frontal thrusts. Their recent investigations on remote dynamic triggering in the Koyna-Warna region show that the dynamic triggering occurred during the 2012 Indian Ocean event $\left(M_{w} 8.6\right)$ and its largest aftershock $\left(M_{w} 8.2\right)$. The enhanced microseismicity in Koyna-Warna region corresponds to propagation of the first few cycles of the Love and Rayleigh waves. These findings suggest the role of dynamic stress change in remote triggering.

\section{Seismicity power laws and its implications}

The natural seismicity may be characterized by the fractal dimension D, Omori's exponent $\mathrm{p}$ and the seismic b-value. Aki (1981) showed a correlation between the b- and D-values as D = 3b/c (c = 1.5). Sunmonu and Dimri (2000) applied fractal analysis to correlate the roughness of faults to seismic activity. Sengupta et al. (2011) analyzed the major fault networks across the country to estimate regional variation in $\mathrm{D}$ values. The high values of fractal dimension, that are associated with the fault network of northwest Himalayas, northeast India and Indo-Gangetic Plains, correlate well with high seismicity rates. On the other hand, low D values for the Indian peninsular shield imply isolated pattern of fault segments. They also showed the variation in $\mathrm{D}$ values with the earthquake source mechanisms: thrust faulting with a high $\mathrm{D}$ and strike-slip faulting with a relatively low $\mathrm{D}$ value.

While interpreting nature of heterogeneities based on fractals for tectonic earthquakes, it can also be extended to triggered seismicity. There has been growing interest where seismicity can theoretically be described in terms of statistical physics; one such component includes intermittent criticality (Main and Al-Kindy, 2002; Bowman and Sammis, 2004). Padhy (2005) examined the critical state of the medium on a regional scale after the 2001 Bhuj earthquake through an entropy-energy relationship based on the tools of statistical mechanics. His results show that $\sim 10 \%$ fluctuations in the thermodynamic variable (entropy) support the intermittent criticality of the region on a regional scale.

In a recent study, Padhy et al. (2015) theoretically assessed bias due to catalog of finite length, scaling range, effects of location errors and boundary effects, and applied it to the 2004 Sumatra earthquake catalog. They found the lower limit of bias in estimates of fractal dimension from limited data sets. Thus, spatial variation in correlation dimensions using local data sets cannot be directly compared unless the influence of bias in the real earthquake catalog is taken into 
account. Subhadra et al. (2018) obtained the bias in fractal dimensions resulting from finite data size by comparing the multi-fractal spectra for the real data and random simulations. The similarity in real and synthetic multi-fractal spectra suggests an only-weakly multi-fractal or a mono-fractal nature of the data. They discussed minimum number of events required for a multi-fractal process with an acceptable error. Their results provide useful constraints on the spatial distribution of the $b$ - and $D$-values, which are useful for seismic hazard assessment. Recently, Subhadra et al. (2018) investigated the yet observed longduration aftershock sequence of the 2001 Bhuj earthquake in western India based on fractal, b-value and static stress analyses, and discussed its implications on seismogenesis and triggering mechanism of the Bhuj aftershocks. Their stress modelling results suggest that most of the 2001 Bhuj aftershocks, preferably of larger magnitude in the sequence, have been triggered by transfer of positive Coulomb stress due to the coseismic slip of the main shock.

Geological features like joints and faults are heterogeneous on scales from $1 \mathrm{~cm}$ to $100 \mathrm{~km}$; different geometries and scaling laws are expected to hold for different scale ranges (Lei et al., 1993). Thus, distribution of the earthquake epicentres in the scale of several kilometres to several thousand kilometres, is not a strict fractal, rather a 'band-limited' fractal because a power law distribution can be possible within each band. Broadly speaking, band-limited or selfaffine fractal can be thought of as a special case of a non-homogeneous fractal (multifractal) that can be used to emphasize the high-resolution properties of heterogeneities. Thus, it is quite interesting to analyze seismically complex areas like the Himalayan belt by applying a multifractal model to distribution of earthquakes in 3-D as a scope of future study.

\section{Seismicity modelling}

Several models of seismicity are proposed over the last decade, which are either physics-based or statistics-based. It has been found that none of the models alone can successfully explain the natural complexity of seismicity; it is rather combination of these can better explain seismicity shown by real earthquakes. One of the widely used models to explain the statistical properties of natural seismicity is the fractal / multi-fractal model that is based on the analysis of the geometry of rough surfaces or of a fractured surface topography. To this end, Bhattacharya et al. (2011) analyzed the fractal topography of the fracture surface. Das et al. (2006) prepared the seismic hazard map of the NE India region by determining the seismic b-value for each site in a grid of equally spaced sites using past earthquake events within a given radius of the site. Bansal and Ogata (2013) suggested Epidemic Type Aftershock Sequence (ETAS) model. Their modeling results, applied to the seismicity in the Sumatra†Andaman Islands region before the 2004 Sumatra earthquake (Mw 9.3), show that the background seismicity rate of the region, relative to the ETAS rate, enhanced $\sim 4$ tyears before the 2004 event. They, on the other hand, did not find any significant change in the observed seismicity rate in the northeastern Himalaya region for the period 1973-2011.

The changes in seismicity (primarily earthquake locations) patterns generally explain the major structural features of any tectonic setting, for instance the subducting (Wadati-Benioff zone) slab is primarily distinguished from the overriding plate and the surrounding mantle based on the location (clustering) of earthquakes, and observations like changes in focal mechanism orientations. There are several evidences showing a link between these two components; we present here some of the recent works on the use of the 2004 Sumatra earthquake to explain such a correlation in a complicated subduction zone structure. Lister et al. (2018) showed a clear analogy between structure of the Sumatran segments and the centroid moment tensors and associated hypocenters based on the analysis of the 2004 Sumatra aftershocks. The velocity structure inferred from seismic tomography clearly corroborates the locations of the earthquakes explaining differentiating the seismic and aseismic features of a region. Similarly, Lange et al. (2018) clearly imaged the subduction zone features (accretionary prism, fore-arc basins, volcanic arc, etc) based on local seismic tomography and earthquake locations. With this in mind, we discuss in the following section the structure of the Indian lithosphere inferred from several techniques.

\section{Structure of Indian Lithosphere}

In this section, we discuss structure of the Indian lithosphere based on analysis of body and surface waves from earthquakes as well as from ambient seismic noise data recorded at regional and teleseismic distances. The shear velocity structures of the crust and upper mantle are investigated in different parts of India using (i) teleseismic converted waves, the receiver function method, (ii) seismic body and surface wave tomography, (iii) inversion of surface wave dispersion, and (iv) their combinations mainly to enhance the resolution. The resolution may be enhanced by a joint inversion of surface wave dispersion and receiver function, or joint analysis of noise-based surface wave dispersion and receiver function. Further, investigations of shallow sub-surface imaging like that of sedimentary basins warrants the use of (i) high-resolution techniques like full waveform inversion for fine-scale imaging, (ii) surface waves at short periods $(<20$ s), or by constraining the seismic tomography images with seismic refraction studies. In the following, we describe some of the major findings on the use of above methods to the Indian lithosphere.

\section{Tectonic domains}

The northward moving Indian plate after continental collision with Asia at $~ 50$ Ma created the world's highest mountain chain, the Himalayas, and the tallest plateau, the Tibetan plateau. The moving Indian lithosphere on interaction with the mantle plume led to the major volcanic eruptions $65 \mathrm{Ma}$ ago over the central-western part of peninsular India, called as the Deccan Volcanic Province (DVP). The Indian subcontinent with several Precambrian cratons are separated by mobile belts and rifts (Fig. 2). The major Precambrian cratons are the Dharwar cratons, Singhbhum craton, Bastar Craton, Bundelkhand Craton and Aravalli craton (Burke et al., 1978). The Dharwar craton is again divided into two, east Dharwar craton and west Dharwar craton, and the southernmost part is named Southern Granulite Terrain (SGT). The prominent mobile belts are the Delhi Aravalli, Satpura and the Eastern Ghat mobile belts. The major rift zones are the Godavari, Mahanadi, Narmada Son, Cambay and Kutch (e.g. Mahadevan, 1998; Raval and Veeraswamy, 2003). The 1000 $\mathrm{km}$ long and $\sim 50 \mathrm{~km}$ wide Narmada-Son rift in the central part of peninsular India is also called Narmada Son Lineament (NSL) zone. The NSL divides the Indian shield in two, to the north the northern shield and to the south the southern shield. The northern Indian shield is covered by thick (up to 3-6 km) Quaternary sediments originating from the Himalayas. The Indo Gangetic Plain (IGP) at the foothill of 


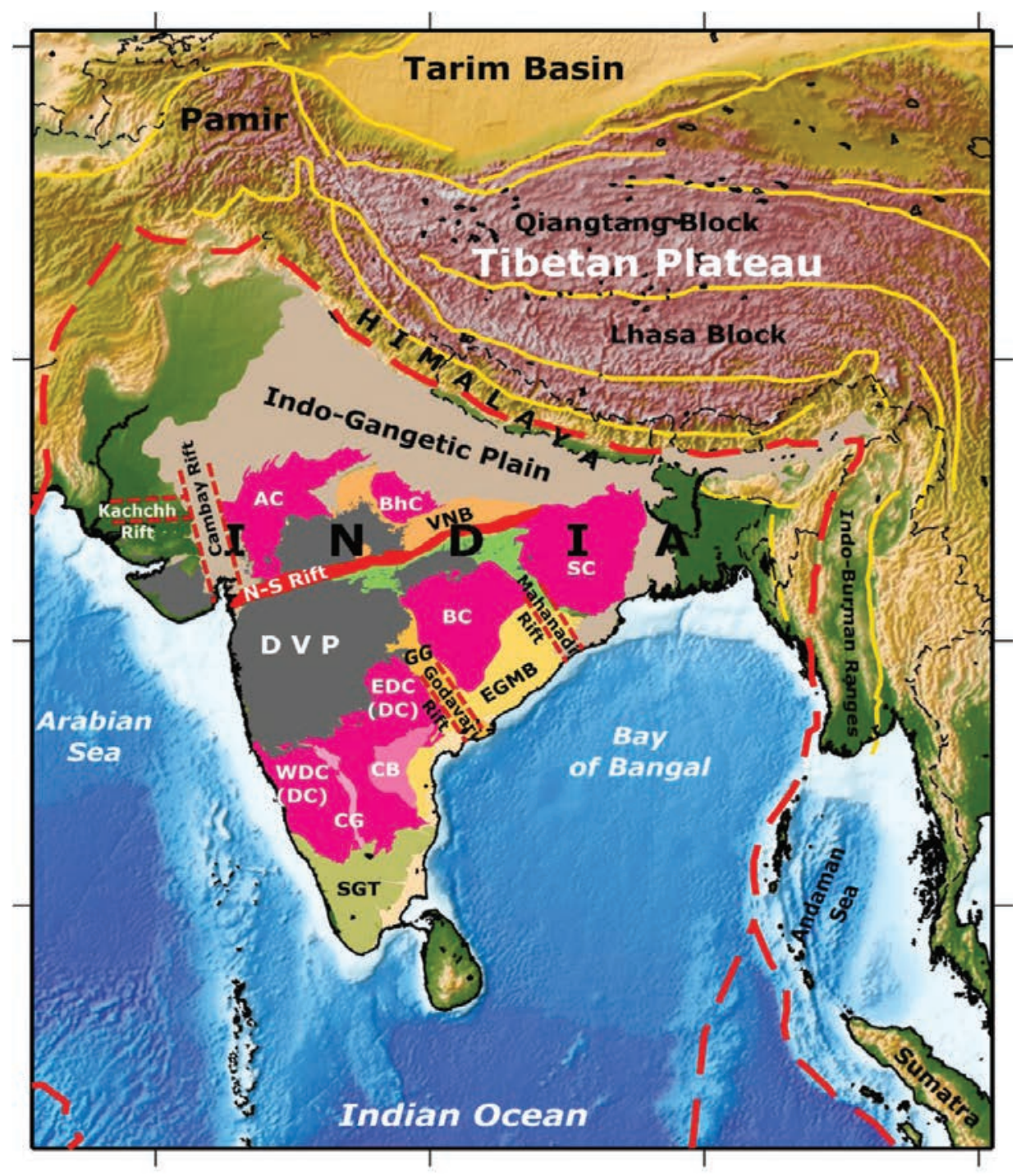

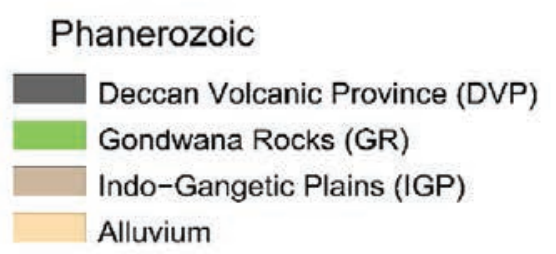

Alluvium

Kennett and Widiyantoro 1999; Kayal et al., 2002; Kayal and Mukhopadhyay, 2002; Mishra et al. 2003; Mandal and Pujol, 2006; Mishra 2013; Singh et al., 2015; Koulakov et al., 2018, 2015; Raoof et al., 2017; Kumar et al., 2017), surface wave tomography (Bhattacharya, 1981; Mitra et al. 2006; Acton et al., 2010), receiver functions (RF) (Rai et al., 2003; Gupta et al., 2003; Kiselev et al., 2008; Ravi Kumar et al., 2013; Kumar et al., 2007, 2013), joint inversion of body and surface wave analyses (Rai et al., 2003; Julia et al., 2009; Saikia et al., 2017), body wave propagation (Krishna et al., 1999; Krishna and Ramesh, 2000), and by magnetotellurics (Gupta et al., 1996; Naganjaneyulu and Santosh, 2012; Pavan Kumar et al., 2017), heat flow (Negi et al., 1986; Roy and Rao, 2000) and xenolith studies (Babu et al., 2009). Lithospheric structures in different tectonic domains are summarized below.

\section{Peninsular India}

The recent $\mathrm{P}$-wave tomography images show thicker lithosphere in northern India with higher Vp anomalies separated from the thinner lithosphere with lower Vp anomalies in southern part, separated by the NSL (Koulakov et al., 2018) (Fig. 3). The variation in crustal thickness for cratons is well documented based on RF analyses (Fig.4), exhibiting crustal / lithospheric thinning related to magmatism associated with the Gondwana break-up episode, and delamination of lithospheric root below the Singhbhum craton (Saul et al., 2000; Sarkar et al., 2003; Mandal 2017). The crustal thickness obtained by integrating active and passive seismic sources is in agreement with the CRUST1.0 (Laske et al., 2013) throughout the continent except for Tibet and east coast of peninsular India with a difference of as large as 20 $\mathrm{km}$ between the two (Singh et al., 2015). There is a good correlation between the 10 s Rayleigh group velocity map and the sediment thickness map of Laske and

the Himalayas and the Bengal basin have thicker sediments with a basement depth in the range 3-8 km below IGP and 15-20 km below the Bengal basin (e.g. Bhattacharya et al., 2010).

\section{Velocity structures}

The velocity structures at different scales of the Indian lithosphere are studied by several researchers employing different approaches such as seismic body wave tomography (Ramesh et al., 1990, 1993;
Masters (1997). The low velocities are associated with sedimentary basins in the Himalayan foredeep, sediments filled Andaman-Sumatra trench, while the higher velocity features correspond to the cratons of the Indian shield (Fig. 5). Kennett and Widiyantoro (1999) obtained an extensive low P-wave velocity anomaly in the upper mantle to the north of the Gulf of Cambay beneath northwestern India. This anomaly is attributed to the Deccan plume, extending from shallow depth down to a depth of $200 \mathrm{~km}$. Singh et al. (2015) reported average crustal 


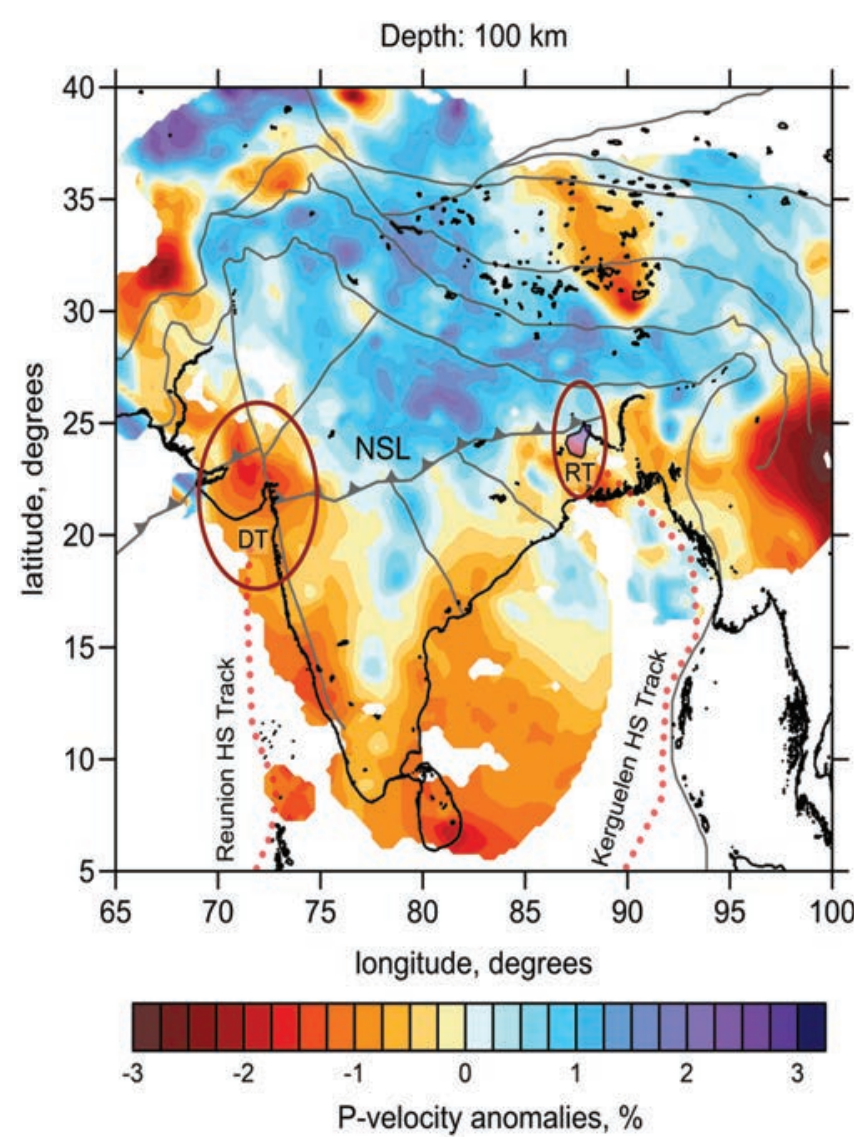

Figure 3. P-wave tomography image of the Indian lithosphere at $100 \mathrm{~km}$ depth. Note the overall high and low Vp anomalies in the northern and southern parts, respectively. The major tectonic elements are marked: NSL with black line and arrows, ellipses DT and RT indicate the Deccan and Rajmahal traps (after Koulakov et al., 2018).

velocity and thickness of the subcontinent using passive seismic, controlled seismic sources and heat flow measurements. Their results show that the variation in crustal thickness across several tectonic blocks (craton, rift, DVP, SGT, Himalaya-Tibet collision zone) significantly deviates from the global model predictions.

The cratonic segments in peninsular India are characterized by higher velocity anomalies $(\sim 3 \%)$ at shallow depths $(<300 \mathrm{~km})$, and the upper mantle low-velocity anomalies are closely related to the Deccan volcanisms and reactivation of the rift systems (Singh et al. 2015). Recently, Maurya et al. (2016) presented a high-resolution 3$\mathrm{D}$ velocity model including anisotropy, and imaged the lithosphere asthenosphere boundary (LAB) and the mid-lithospheric discontinuities of the Indian plate based on surface wave tomography using a massive dataset of 550 seismic broadband stations. In addition, some theoretical studies on receiver function, such as obtaining the response at the receiver without deconvolution (Kumar et al., 2010), sparsely constrained compressive time domain deconvolution (Sen et al., 2014) and transmitted P-to-S amplitude variation with ray parameter (Kumar et al., 2014) are made that show promising results.

\section{Tibet-Himalaya collision zone}

The lithospheric structure beneath Tibet and the Himalayas is investigated based on surface-wave studies (Brandon and Romanowicz, 1986; Curtis and Woodhouse, 1997; Rodgers and Schwartz, 1998; Rapine et al., 2003), high-frequency body wave propagation (Barazangi and Ni, 1982; McNamara et al., 1997), bodywave studies employing the P- and S-wave receiver functions (Rai et al., 2006; Vinnik et al., 2007; Zhao et al., 2011; Singh and Kumar, 2009; Xu et al. 2017; Hazarika et al. 2012; Kumar et al., 2013; Caldwell et al., 2013; Gilligan et al., 2015), body wave travel-time tomography (Tilmann et al. 2003; Koulakov et al., 2015; Raoof et al., 2017), integrated seismic data including receiver functions and mantle anisotropy (Oreshin et al., 2008), finite-frequency tomography using teleseismic data (Liang et al., 2016). Their results show undulated mantle structure along the Himalayas as well as striking difference in mantle structure between the northern and southern Tibet, higher velocity, presumably colder and stronger mantle beneath southern Tibet versus slower, presumably warmer and weaker mantle beneath northern Tibet. The nature of mantle heterogeneities supports under thrusting of the Indian lithosphere near the middle of the Tibetan plateau. Under the INDEPTH III multi-disciplinary project, Tilmann et al. (2003) presented a high-resolution P-wave velocity model of the Indian lithosphere beneath central Tibet. They reported a subvertical high velocity zone in the $\sim 100-400 \mathrm{~km}$ depth range as the downwelling Indian mantle lithosphere, implying a warmer mantle beneath central Tibet. An intra-crustal discontinuity observed at 55 $\mathrm{km}$ depth below the southern Lhasa in Tibet is attributed to the upper boundary of eclogite within the under thrusting Indian lower crust (Xu et al., 2017). The LAB-related Sp conversions at $\sim 130-200 \mathrm{~km}$ depth suggest that the Indian lithospheric mantle is under thrusting with a ramp-flat shape beneath southern Tibet. The high-velocity bodies dipping at $\sim 40^{\circ}$ northward beneath the Himalayas and Tibet are interpreted as the subducting Indian Continental Lithosphere (ICL) (Liang et al., 2016). Rifting in central and southern Tibet is associated with low-velocity anomaly extending from lower crust to more than $300 \mathrm{~km}$ depth; thus the northward fragmented moving Indian plate induces asthenospheric upwelling similar to that prevails in the upper mantle of northern Tibet. The India-Asia collision zone (Tidding Suture) is only $\sim 55 \mathrm{~km}$ thick compared to an overall crustal thickness $>70 \mathrm{~km}$ in the northwest and central Himalayas (Hazarika et al., 2012).

\section{Northeast India Region}

The lithosphere is $\sim 90 \mathrm{~km}$ thick beneath the Shillong plateau, suggesting a lithospheric up warp related to the plateau uplift (Uma Devi et al., 2011). Recently, Mitra et al. (2018) presented an improved structure model of the continental crust beneath the Brahmaputra valley, Shillong plateau and Mikir hills and of the transitional crust beneath the Bengal basin based on the P-wave RF analysis and joint inversion of receiver function and Rayleigh wave group velocity dispersion data. Their model shows the thinnest continental crust $(30 \pm 2 \mathrm{~km})$ in central Shillong plateau and Mikir hills with an increased thickness to both its north and south by $\sim 10 \mathrm{~km}$.

The seismic tomographic images of NE India and its adjoining areas shows high velocity dipping structures related to the under thrusting Indian lithosphere under the Himalayas and below the IndoBurma ranges, Shillong plateau, the eastern Himalaya syntaxis, and low velocity thick sediments below the Bengal basin (Bhattacharya et al., 2010; Raoof et al., 2017). Raoof et al. (2017) reported that the subducting Indian lithosphere goes down to $\sim 600 \mathrm{~km}$ below the Indo- 
Burma ranges. They also proposed that the lithosphere is buckled up below NE India and the crest of the buckled up part lies below Shillong

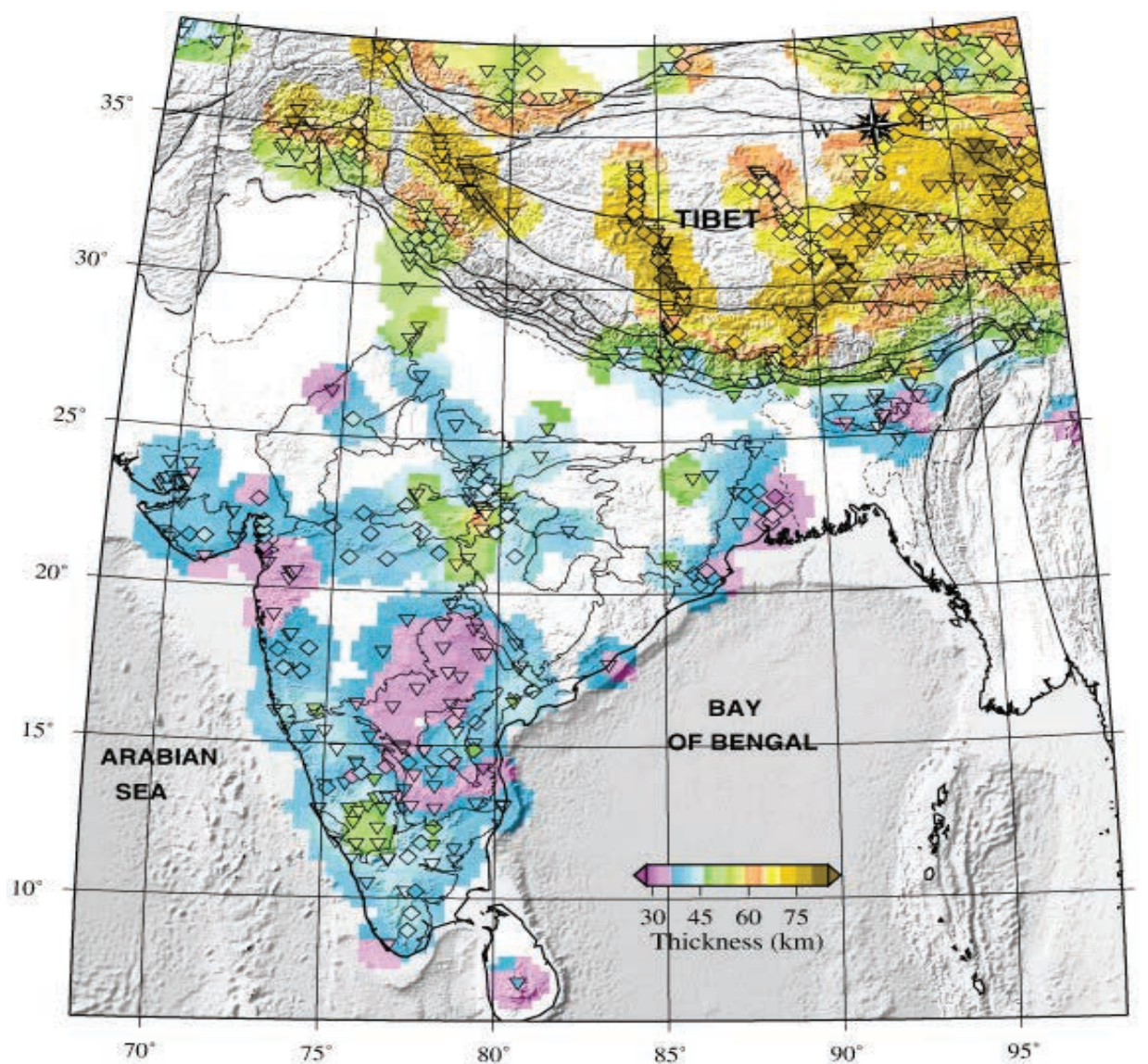

Figure 4. Map of crustal thickness obtained from receiver functions constrained by deep seismic sounding (after Singh et al., 2015).

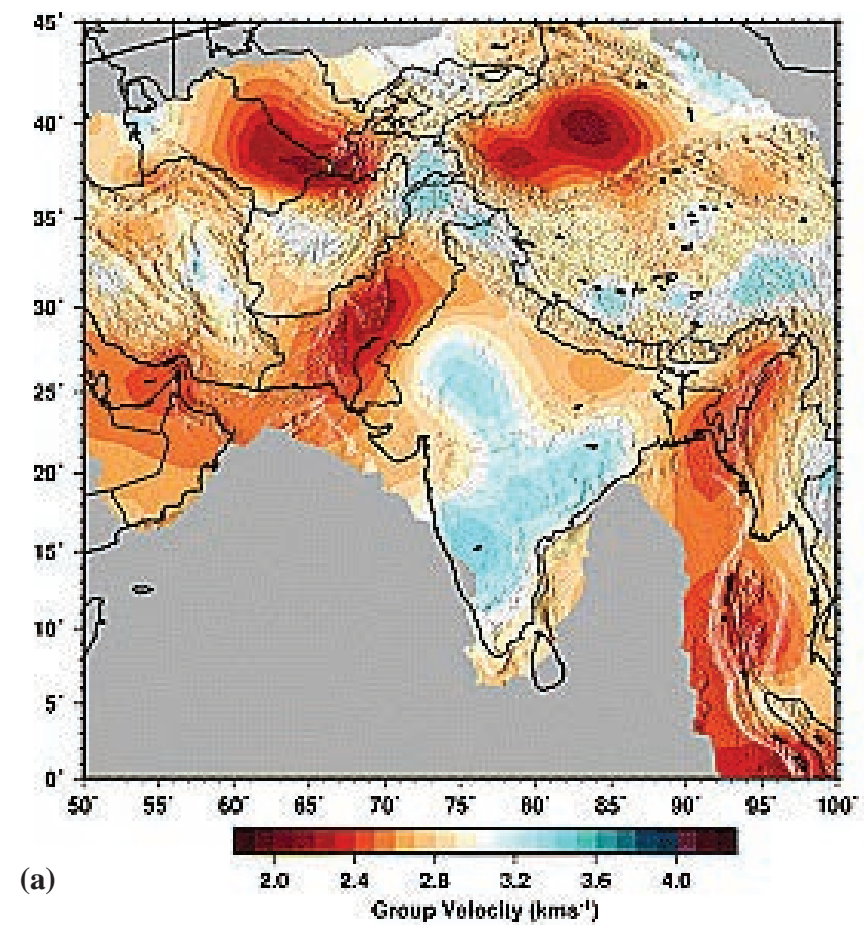

plateau and Mikir Hills. Based on surface wave dispersion analyses in 15-120 s, the S-wave velocity structure of the crust and upper mantle was studied below Bay of Bengal (Kumar et al., 2018). Their results show that the nature of crust changes from more oceanic type in the southern part to more continental type to the north of the Bay with the mantle structure showing complex variation from south to north.

Receiver function analysis of the recent broadband teleseismic data (Kumar et al., 2004; Mitra et al., 2005; Ramesh et al., 2005), however, shows that the crust is thinner ( 35-38 km) beneath the Shillong plateau. The Moho beneath the northern part of Bengal basin to the south of the plateau is at a depth of $\sim 44 \mathrm{~km}$ and beneath the Brahmaputra valley to the north, the Moho depth is 40-42 km, deeper by 5-7 km than below the Shillong plateau. Further north of the foredeep, the Moho dips gently northward reaching a depth of $\sim 48 \mathrm{~km}$ beneath the Arunachal Himalaya, and 88 km below Lasha in Tibet (Mitra et al., 2005).

\section{Rheology of Lithosphere}

A few studies are made on the rheology of Indian lithosphere (e.g.

Figure 5. (a) Rayleigh wave fundamental group velocity map for 10 s period. (b) Sediment thickness map taken from Laske and Masters (1997) (after Acton et al., 2010). 
Hetenyi et al. 2006; Priestley et al. 2008). The effective elastic thickness (EET) of the Indian plate is estimated along a south-north broadband-seismic profile extending from the Ganges basin to central Tibet, Bouguer anomaly profiles and by deep well measurements and 2-D thermo-mechanical modelling. Hetenyi et al. (2006) reported that the EET of the Indian plate decreases northwards from $60-80 \mathrm{~km}$ to 20-30 km as it is flexed beneath the Himalayas and Tibet due to thermal and flexural weakening. Priestley et al. (2008) inferred the rheology of the lithosphere beneath the Himalaya-Tibet collision zone from the joint inversion of receiver function and surface wave dispersion data with their implications on depth distribution of earthquakes in the region. They suggested that relatively lower mantle temperature $\left(<\sim 600^{\circ} \mathrm{C}\right)$ together with a 'ramp-and-flat' geometry of the Indian basement may be responsible for earthquakes in the lower crust and upper mantle.

\section{Seismic Anisotropy}

There are significant studies on seismic anisotropy in upper mantle for different tectonic units of the Indian continent with varied geological terrains, including the cratons, the continental margins along the west and east coasts, DVP, SGT, Himalayan arc, IndusTsangpo suture zone, Tibet and Indian ocean from analysis of direct and core-refracted S-wave phases (SKS, SKKS, PKS, ScS) (Saikia et al. 2010; Rao et al., 2013; Roy et al., 2012; Ravi Kumar et al., 2008; Singh et al., 2006, 2007, 2015; Vinnik et al., 2007; Heintz et al., 2009; Rao and Kumar, 2014; Pavan Kumar et al., 2015; Rao et al., 2017). The time delay between the split shear waves and their fast polarization direction were used to characterize the nature of anisotropy. The overall findings of the above studies tell us about the mechanisms involved in the India-Eurasia collision along the Himalayan arc. Of particular interest is the station HYB on the Indian shield, results from the earlier (Barruol and Hoffmann, 1999) and current study are strikingly different. Forward modeling of anisotropy with an assumed horizontal axis of symmetry gives rise to a twolayered anisotropic model beneath the Indian shield with fast orientation $\mathrm{N} 15^{\circ} \mathrm{E}$ and stronger anisotropy $(\delta \mathrm{t} \approx 1 \mathrm{~s})$ in the bottom layer related to asthenospheric flow and $\mathrm{N} 60^{\circ} \mathrm{E}$ with a weaker one $(\delta \mathrm{t} \approx 0.4 \mathrm{~s})$ in the top layer representing frozen fabrics in the lithosphere (Saikia et al., 2010). Roy et al. (2014) studied seismic velocity anisotropy beneath Indian lithosphere inferred from splitting of SKS and SKKS phases. Their results show mantle anisotropy caused by development of lithospheric strain and by relative plate movement in the Himalayan foredeep and Indian craton, respectively. There is a strong evidence of seismic anisotropy to the south of Indus Tsangpo suture zone; dominance of the asthenospheric flow contributes to upper mantle anisotropy beneath the Indian lithosphere (Heintz et al., 2009). The Dharwar craton in Indian shield is characterized by a 150-200-km-thick anisotropic layer correlating with the lithospheric root, while the Pan-African SGT by an internally deformed and thin anisotropic layer (Pavan Kumar et al., 2015). The south Indian shield that is characterized by a layered anisotropic lithosphere as inferred from $90^{\circ}$ periodicity of the two anisotropy parameters is the result of complex interplay between the Archean craton and its subsequent deformation due to deep Earth processes (Pavan Kumar et al., 2015). The seismic anisotropy of the lowermost mantle beneath the Indian Ocean Geoid Low (IOGL) was investigated by analyzing splitting of high quality ScS phases (Rao and Ravi Kumar, 2014). Results reveal significant anisotropy in the D” layer with a TTI (transverse isotropy with a tilted axis of symmetry). They suggested that the high velocities in the upper mantle beneath foothills of the western Himalaya correspond to a near-horizontal mantle keel of the Indian shield rather than the ongoing subduction. The anomalous velocity and thickness, as inferred from joint inversion of SKS particle motion and P receiver functions, can be explained by scraping off the lower crust, when the Indian lithosphere underthrusts the Himalayas (Vinnik et al., 2007).

Anisotropy is also observed in the crust as inferred from analysis of shear waves of local earthquakes. Few interesting findings include those obtained from aftershock records of the 2001 Bhuj earthquake in western India (Padhy and Crampin, 2006; Mandal, 2009) and data recorded by a cluster broadband network in northeast India region (Sharma et al., 2017). The crustal anisotropy may be stress induced or structure related. A $90^{\circ}$ flip in fast polarization directions indicate the presence of critically high pore-fluid pressures in the fault zone of the 2001 Bhuj earthquake. However, the sources of strong scattering from the highly heterogeneous crust hinders to clearly visualize anisotropy in the crust. Mishra and Zhao (2003) quantitatively estimated crack density, saturation rate, porosity parameters and Poisson's ratio from seismic velocities to characterize the nature of rock materials and hence the velocity anisotropy. For example, based on higher values of the above parameters they suggest that occurrence of the 2001 Bhuj earthquake is related to in-situ material heterogeneities, rather than stress conditions alone.

\section{Ambient Seismic Noise}

Recent advances in seismic methods make use of ambient noise recorded at a pair of stations to image the underlying structure without the use of earthquakes or explosions, and with no need of information about the medium. By cross-correlating seismic observations at different receiver locations, surface waves (empirical Green's function) propagating between stations can be reconstructed because of their high signal to noise ratio with no need of information about the medium (Snieder, 2004; Shapiro and Campillo, 2004; Shapiro et al. 2005; Calkins et al., 2011; Snieder and Wapenaar, 2010). Then with a treatment similar to surface wave dispersion measurements, one can obtain a 3-D velocity structure of the medium by analyzing the Green's functions obtained with an array of stations for many ray paths. This method of extracting the 3-D structure using ambient noise is referred to as the ambient noise tomography (ANT) that can produce shear wave velocity images for different frequencies with a resolution higher than that obtained by traditional tomography. It has wide applications ranging from basin imaging in small-scale to imaging structures on continental scale (Campillo and Paul, 2003; Shapiro et al., 2005).

In India, a few studies are carried out to image the subsurface based on the use of ambient noise (e.g. Singh et al., 2011; Borah et al., 2014; Rohilla et al., 2015; Das and Rai, 2017). Borah et al. (2014) imaged the crust beneath the Dharwar Craton, based on joint analyses of ambient noise (surface wave dispersion in 5-28 s) and teleseismic earthquake data (receiver function analyses in 40-70s). They could resolve the difference in thickness and composition of the crust between the eastern and western Dharwar cratons. Rohilla et al. (2015) determined the shear-wave velocity structure of the Koyna-Warna region in western India using noise-based surface wave dispersion measurements. Their results show variation in thickness and shearwave velocity for the basaltic layer of the Deccan traps of the region. Recently, Das and Rai (2017) determined radial anisotropy in upper 
and lower crust based on Rayleigh and Love wave dispersion measurements in 2-32 s using the ambient noise data recorded at 57 sites in southern India. A maximum of 5\% anisotropy in lower crust is inferred due to the presence of micaceous minerals in the deeper crust. One can study joint analysis of body and surface wave extracted from noise sources in order to resolve structures better than that obtained with traditional methods using earthquake data. Another possibility is to study jointly ANT and travel-time tomography for resolving local anomalies which is not better resolved by the latter once the ray coverage is poor.

\section{Seismic Attenuation}

Seismic waves experience attenuation, decay in amplitude with distance, as they propagate through the Earth medium. The attenuation is expressed in terms of the dimensionless quality factor Q, which is defined as the loss of energy per unit cycle of the wave. It is one of the important parameters that not only describes velocity and thermal structure, volcanism and subduction zones, but characterizes earthquake source and path effects (intrinsic attenuation) ultimately defining the level of earthquake ground motions for hazard assessment. The frequency-dependent 3-D attenuation structure of the crust is obtained from inversion of the spectral acceleration using strongmotion (Joshi et al., 2010; Kumar et al., 2015; ) and seismic intensity data (Joshi 2007) in Kumaon Himalaya and central gap region of Himalayas, which can be used for prediction of ground motion and hence for hazard assessment of the region. Seismic wave attenuation has been investigated for different parts of India on local to regional scale using the high-frequency $(>1 \mathrm{~Hz})$ direct body and the following coda waves; these waves in this frequency band resolves features of the crust and upper mantle with a scale length of the order of few kilometers in crust to few hundred kilometers in upper mantle. The seismic waves experience strong scattering when their wavelengths are of the same order as the scale lengths of heterogeneities.

Several researchers characterized the nature of small-scale medium heterogeneities for different parts of India based on attenuation analyses of body and coda waves at high frequencies (Parvez et al., 2008; Rai et al., 2009; Mukhopadhyay et al., 2008, 2010; Tripathy et al., 2014; Padhy et al., 2007, Padhy and Subhadra, 2009, 2010). They studied in detail the frequency, lapse-time, and depth dependences of attenuation and correlated the results with regional seismicity. A simple scattering model with frequency independent intrinsic absorption shows peak attenuation around $0.5 \mathrm{~Hz}$ as found from findings of coda wave analysis globally (Padhy, 2005), although more advanced scattering models are needed to better explain their frequency dependency (Sato et al., 2012).

Both single and multiple scattering theories are adopted to constrain the attenuation parameters. Attenuation of seismic waves is caused by both scattering attenuation from distributed heterogeneities and intrinsic attenuation, i.e. loss of energy because of anelastic nature of rocks. Resolving their mechanisms is a challenge in high-frequency seismology. Approaches like multiple lapse time window analysis (MLTWA) and inversion of seismogram envelopes based on radiative transfer theory (RTT) are used to separate scattering and intrinsic attenuation (Singh et al., 2016; Ugalde et al., 2006, 2007; Padhy et al., 2007; Padhy and Subhadra 2015). It is worth noting that the frequency dependences of intrinsic $Q\left(Q_{i}\right)$ and scattering $Q\left(Q_{s c}\right)$ estimated in the same area with the same dataset may differ significantly, which are attributed to differences in models used, which are far from reality. For example, most of the studies on coda attenuation use multiple isotropic scattering in a uniform half-space model with non-isotropic source radiation. In such cases, the attenuation parameters are biased. The leakage of energy from the crust to the underlying mantle is neglected in uniform half space models. Thus, a model incorporating non-isotropic scattering of seismic waves in a depth varying velocity structure is needed to obtain more appropriate results. In addition to body wave attenuation, of surface (Lg) waves was studied in peninsular India based on anlysis of regional earthquakes (Singh et al., 1999, 2004; Mitra et al., 2006). The $\mathrm{Q}_{\mathrm{Lg}}$ estimates have important implications for prediction of ground motions. Singh et al. (2015) studied lateral variation of $\mathrm{Q}_{\mathrm{Lg}}$ in the crust beneath the Himalayas and southern Tibet based on regionalization of the $\mathrm{Lg} \mathrm{Q}$ values obtained with a two-station method. Their attenuation model shows the lowest value $\left(\mathrm{Q}_{\mathrm{Lg}}<50\right)$ along the Main Central Thrust (MCT) in Sikkim, in Lesser Himalaya and in some parts of the Greater Himalayas. The zones with relatively higher attenuation could be attributed to thermal effects, presence of aqueous fluids and structural heterogeneities in the region.

\section{Conclusions}

It may be concluded that seismicity of the Indian subcontinent is instrumentally fairly well recorded since say 1964 with the WWSSN along with the national seismological network. Since early 1990, and subsequent upgrading of the network with digital instrumentation in late 1990s, substantial improvement of recording and locating of earthquakes are achieved; particularly aftershock sequences of the strong/large/great earthquakes in different tectonic zones are much well studied. The Koyna-Warna region in the SCR India, on the other hand, provided an excellent opportunity to understand the reservoir triggered seismicity. Enhanced triggered seismicity in the Indian ocean intraplate region is also recorded after the 2004 mega earthquake $\left(\mathrm{M}_{\mathrm{w}}\right.$ 9.3) at the Andaman-Sumatra subduction zone.

A good number of velocity models at local to regional scale are obtained for the Indian lithosphere including the peninsular India shield region, the Himalayan foredeep and collision zone, the NE India intraplate as well as the Indo-Burma and Andaman-Sumatra subduction zones. Various studies are made using body wave (receiver function, travel-time tomography, and seismic anisotropy), surface wave analyses (dispersion measurements, and ambient noise tomography) and their joint inversion. There are ongoing efforts to further improve the resolution of the models by integrating both active and continuously monitored passive seismic data. It is, however, needed to prepare seismic catalogue with a magnitude completeness as small as possible that is feasible with recording of microearthquakes with deployment of dense seismic networks on regional scale. This high-frequency data set would advance our understanding not only on the background versus triggered seismicity, but would allow us for obtaining a fine-scaled high-resolution structure as a key element for ground motion prediction and hence for hazard assessment of any region.

\section{Acknowledgements}

We sincerely thank three anonymous reviewers and the guest editor Dr. V. M. Tiwari for constructive comments that improved the quality of this work. Director, CSIR-NGRI, Hyderabad for inviting 
to contribute this review work to the 36th IGC special issue of Episodes. Padhy thanks the Director, CSIR-NGRI for his kind permission and encouragement.

\section{References}

Acton, C.E., Priestley, K., Gaur, V.K., and Rai, S.S., 2010, Group velocity tomography of the Indo Eurasiancollision zone. Journal Geophysical Research, doi:10.1029/2009JB007021.

Aki, K., 1981, Probabilistic synthesis of precursory phenomena. In: Earthquake Prediction: An International Review, D. W. Smpson, P.G. Richards (Eds.), Maurice Ewing Series 4, AGU pub., pp. 566-574.

Andrade, V., Rajendran, K., 2014, The April 2012 Indian Ocean earthquakes: Seismotectonic context and implications for their mechanisms. Tectonophysics, v. 617, pp. 126-139.

Arora, K., Srinu, Y., Gopinadh, D., Chadha, R.K., Raza, H., Mikhailov, V., Ponomarev, A., Kiseleva, E., and Smirnov, V., 2018, Lineaments in Deccan Basalts: The basement connection in the Koyna-Warna RTS region. Bulletin Seismological Society America, v. 108, pp. 2919-2932.

Babu, E.V.S.S.K., Bhaskar Rao, Y.J., mainkar, D., Pashine, J.K., Shrikant Rao, R., 2009, Mantle xenoliths from the Kodomali kimberlite pipe, Bastor Craton, central India,: Evidence fordecompression melting and crustal contamination in the mantle source. Geochim. Cosmochim. Acta Goldschmidt Abstracts., v. 73, pp. A66.

Bansal, A.R., and Ogata, Y., 2013, A non-stationary epidemic type aftershock sequence model for seismicity prior to the December 26, 2004 M 9.1 Sumatra-Andaman Islands mega†earthquake. Journal Geophysical Research: Solid Earth, v. 118 (2), pp. 616629.

Bansal, A.R., Yao, D., Peng, Z., and Sianipar, D., 2016, Isolated regions of remote triggering in south/southeast Asia following the $2012 \mathrm{Mw}$ 8.6 Indian Ocean earthquake. Geophysical Research Letters, v. 43 (20), pp. 10,654-10,662.

Barazangi, M., and Ni, J., 1982, Velocities and propagation characteristics of Pn and Sn beneath the Himalayan arc and Tibetan plateau: Possible evidence for underthrusting of Indian continental lithosphere beneath Tibet. Geology, v. 10 (4), pp. 179-185.

Barruol, G., and Hoffmann, R., 1999, Upper mantle anisotropy beneath the Geoscope stations. Journal Geophysical Research: Solid Earth, v.104, pp. 10757-10773.

Bendick, R., and Bilham, R., 2001, How perfect is the Himalayan arc?: Geology, v. 29, pp. 791- 794.

Bhattaccharya, S.N., 1981. Observation and inversion of surface wave group velocities across central India. Bulletin Seismological Society America, v. 71 (5), pp. 1489-1501.

Bhattacharaya, Pankaj M., Kayal, J. R, Baruah, Saurabh, Arefiev, S.., 2010. Earthquake Source Zones in northeast India: Seismic Tomography, Fractal Dimension and b Value Mapping, Pure and Applied Geophysics., DOI 10.1007/s00024-010-0084-2.

Bhattacharya, P., Chakrabarti, B. K., and Kamal, 2011, A fractal model of earthquake occurrence: Theory, simulations and comparisons with the aftershock data. Continuum models and discrete systems symposia (CMDS-12) IOP Publishing Journal of Physics: Conference Series 319012004. doi:10.1088/1742-6596/319/1/ 012004.

Borah, K., Rai, S.S., Prakasam, K.S., Gupta, S., Priestley, K., and Gaur, V.K., 2014, Seismic imaging of crust beneath the Dharwar craton, India: inference from ambient noise tomography and teleseismic receiver function modelling. Geophysical Journal International, v. 197, pp. 748-767.
Bowman, D.D., and Sammis, C., 2004, Intermittent Criticality and the Gutenberg-Richter Distribution. Pure and Applied Geophysics, v.161 (9), pp. 1945-1956.

Brandon, C., and Romanowicz, B., 1986, A no-lid zone in the central Chang Thang platform of Tibet: evidence from pure path phase velocities of long period Rayleigh waves. Journal Geophysical Research., v. 91, pp. 6547-6564.

Burke, K., Dewey, L., Edelstein, A., Kidd., W.S.F., Nelson, K.D., Sengor, A.M.C. and Stroup, J., 1978. Rift and sutures of the world (NASA-CR-175201) compiled for Goddard Space Flight Center, Greenbelt, Maryland. Albany Global Tectonics Group, State Univ. New York, Albany, NY, 238p.

Caldwell, W.B., Klemperer, S.L., Lawrence, J.F., Rai, S.S., and Ashish, 2013, Characterizing the Main Himalayan Thrust in the Garhwal Himalaya, India with receiver function CCP stacking. Earth Planetary Science Letters, v. 367, pp. 15-27.

Calkins, J.A., Abers, G.A., Ekström, G., Creager, K.C., and Rondenay, S., 2011, Shallow structure of the Cascadia subduction zone beneath western Washington from spectral ambient noise correlation. Journal Geophysical Research, v. 116, B07302, doi:10.1029/2010JB007657.

Campillo, M., and Paul, A., 2003, Long-Range Correlations in the diffuse seismic coda. Science, v. 299, pp. 547.

Curtis, A., and Woodhouse, J.H., 1997, Crust and upper mantle shear velocity structure beneath the Tibetan plateau and surrounding regions from interevent surface wave phase velocity inversion. Journal Geophysical Research, v. 102, pp. 11,789-11,813.

Das, R., Sharma, M.L., and Wason, H.R., 2016. Probabilistic Seismic Hazard Assessment for Northeast India Region. Pure and applied Geophysics, v. 173, pp. 2653-2670.

Das, R., and Rai, S.S., 2017, Extensive seismic anisotropy in the lower crust of Archean metamorphic terrain, South India, inferred from ambient noise tomography. Tectonophysics, v. 694, pp. 164180 .

Dattatrayam, R.S., Suresh, G., Baidya, P.R., Prakash, R., Gautam, J.L., Shukla, H.P., and Singh, D., 2014, Standards and methodologies of seismological data generation, processing and archival \&amp; guidelines for data sharing and supply. Proc. Indian National Science Academy, v. 80, pp. 679-696.

DeMets, C., R. G. Gordon, D. F. Argus, and S. Stein (1990), Current plate motions, Geophysical Journal International, v. 101, pp. 5478.

Dev, S.M.S.P., and R. Nagarajan, R., 2017, Seismic hazard assessment of Koyna region, Peninsular India: using geospatial approach. Geoenvironmental Disasters, v. 4, DOI 10.1186/s40677-0170092-y.

Dixit, M., Singh, A.P., Mishra, O.P., 2017, Rayleigh wave group velocity tomography of Gujarat region, western India and its implications to mantle dynamics. Journal Seismology, v. 21, pp. 809-823.

Felher, M. Hoshiba, M., Sato, H., and Obara, K., 1992, Separation of scattering and intrinsic attenuation for the Kanto-Tokai region, Japan, using measurements of S-wave energy vs. hypocentral distance. Geophysical Journal Inernational, v. 108, pp. 787-800.

Gahalaut, V.K., Kundu, B., Singh, S., Laishram, Catherine, J., Kumar, A., Singh, M.D., Tiwari, R.P., Chadha, R.K., Samanta, S.K., Ambikapathy, A., Mahesh, P., Bansal, A., and Narsaiah, M., 2013, Aseismic plate boundary in the Indo-Burmese wedge, northwest Sunda Arc. Geology, v. 41, pp. 235-238.

Gilligan, A., Priestley, K.F., Roecker, S.W., Levin, V., and Rai, S.S., 2015, The crustal structure of the western Himalayas and Tibet. Journal Geophysical Research: Solid Earth, v. 120 (5), pp. 39463964.

Gupta, H.K., Sarma, S.V.S., Harinarayana, T., Virupakshi, G., 1996, 
Fluids below the hypocentral region of Latur earthquake, India: Geophysical indicators. Geophysical Research Letters, v. 23 (13), pp. 1569-1572.

Gupta, H.K., 2001, Short-term earthquake forecasting may be feasible at Koyna, India. Tectonophysics, v. 338, pp. 353-357.

Gupta, S., Rai, S.S., Prakasam, K.S., Srinagesh, D., Bansal, B.K., Chadha, R.K., 2003, The nature of the crust in southern India: implications for Precambrian crustal evolution. Geophysical Research Letters, v. 30 (8), https://doi.org/10.1029/ 2002GL016770.

Gupta, H.K., 2018, Review: Reservoir triggered seismicity (RTS) at Koyna, India, over the Past 50 Yrs. Bulletin Seismological Society America, v. 108 (5B), pp. 2907-2918.

Gutenberg, B., and Richter, C.F., 1954, Seismicity of the earth and associated phenomena. Princeton University Press, Princeton, NJ, USA.

Hayes, G.P., Briggs,R.W., Barnhart, W.D., Yeck, W.L., McNamara, D.E., Wald, D.J., Nealy,J.L., Benz,H.M., Gold,R.D., Jaiswal,K.S., Marano,K., Earle,P.S., Hearne,M.G., Smoczyk,G.M., Wald,L.A., and Samsonov, S.V., 2015. Rapid characterization of the 2015 Mw 7.8 Gorkha, Nepal, earthquake sequence and its seismotectonic context, Seismol. Res. Lett., v. 86 (6), pp.15571567.

Hazarika, D., Arora, B.R., and Bora, C., 2012, Crustal structure and deformation in the northeast India- Asia collision zone: constraints from receiver function analysis. Geophysical Journal International, v. 188, pp. 737-749.

Heintz, M., Kumar P.V., Gaur, V.K., Priestley, K. and Rai, S.S., 2009, Anisotropy of the Indian continental lithospheric mantle. Geophysical Journal International, v. 179, pp. 1341-1360.

Hetenyi, G., Cattin, R., Vergne, J., and Nabelek, J.L., 2006. The effective elastic thickness of the India Plate from receiver function imaging, gravity anomalies and thermomechanical modelling. Geophysical Journal International, v. 167, pp. 1106-1118.

Indian standard (IS), 2002, Criteria for earthquake resistant design of structures, part 1 General provisions and buildings (Fifth revision). IS 1893 (Part 1), Bureau of Indian Standards (BIS), New Delhi, India, pp. 1-38.

Joshi, A., 2007, Inversion of seismic intensity data for the determination of three-dimensional attenuation structures in the central gap region of Himalayas. Natural Hazards, v. 43 (1), pp. $1-22$.

Joshi, A., Mohanty, M., Bansal, A.R., Dimri, V.P., and Chadha, R.K., 2010, Use of spectral acceleration data for determination of threedimensional attenuation structure in the Pithoragarh region of Kumaon Himalaya . Journal Seismology, v. 14, pp. 247-272.

Julia, J., Jagadeesh, S., Rai, S.S., Owens, T.J., 2009, Deep crustal structure of the Indian shield from joint inversion of $\mathrm{P}$ wave receiver functions and Rayleigh wave group velocities: implications for Precambrian crustal evolution. Journal of Geophysical Research: Solid Earth, v. 114 (B10), https://doi.org/ 10. 1029/ 2008JB006261.

Kayal, J.R., Zhao, D., Mishra, O.P., De, R., and Singh, O.P., 2002, The 2001 Bhuj earthquake: Tomographic evidence for fluids at the hypocenter and its implications for rupture nucleation, Geophysical Research Letters, 29 (24), 51-54.

Kayal, J.R., and Mukhopadhyay, M., 2002, Seismic tomography structure of the 1993 Killari earthquake source area. Bulletin Seismological Society America, v. 92 (5), pp. 2036-2039.

Kayal, J.R., 2007. Recent large earthquakes in India: Seismo-tectonic perspective. 2007 International Association for Gondwana Research, Japan. IAGR Memoir No. 10, pp. 189-199.

Kayal, J.R., 2008, Microearthquake seismology and seismotectonics of south Asia. Springer, Dordrecht. DOI https://doi.org/10.1007/
978-1-4020-8180-4.

Kayal, J.R., Arefiev, S.S., Baruah, S., Tatevossian, R., Gogoi, N., Sanoujam, M., Gautam, J.L, Hazarika, D., and Borah, D., 2010, The 2009 Bhutan and Assam felt earthquakes (Mw 6.3 and 5.1) at the Kopili fault in the northeast Himalaya region. Geomatics, Natural Hazards and Risk, v. 1, pp. 273-281.

Kennett, B.L.N., and Widiyantoro, S., 1999, A low seismic wavespeed anomaly beneath northwestern India: a seismic signature of the Deccan plume? Earth and Planetary Science Letters, v. 165, pp. 145-155.

Khattri, K.N., 1999, Probabilities of occurrence of great earthquakes in the Himalaya. Proc. Indian Acad. Sci. (Earth Planet. Sci.), v. 108, pp. 87-92.

Kiselev, S., Vinnik, S., Oreshin, S., Gupta, S., Rai, S.S., Singh, A., Kumar, M.R., and Mohan, G., 2008, Lithosphere of the Dharwar craton by joint inversion of $\mathrm{P}$ and $\mathrm{S}$ receiver functions. Geophysical Journal International, v. 173 (3), pp. 1106-1118.

Koulakov, I., Maksotova, G., Mukhopadhyay, S., Raoof, J., Kayal, J.R., A Jakovlev, A Vasilevsky, 2015, Variations of the crustal thickness in Nepal Himalayas based on tomographic inversion of regional earthquake data. Solid Earth, v. 6 (1), pp. 207.

Koulakov, I., Gerya, T., Rastogi, B.K., Jakovlev, A., Medved, I., Kayal, J.R., El Khrepy, S., and Al- Arifi, N., 2018, Growth of mountain belts in central Asia triggers a new collision zone in central India. Scientific reports, v. 8, DOI:10.1038/s41598-018-29105-2.

Krishna, V.G., Rao, C., Gupta, H.K., Sarkar, D., and Baumbach, M., 1999, Crustal seismic velocity structure in the epicentral region of the Latur earthquake (September 29, 1993), southern India: inferences from modelling of the aftershock seismograms. Tectonophysics, v. 304 (3), pp. 241-255.

Krishna, V.G., and Ramesh, D.S., 2000, Propagation of crustalwaveguide-trapped Pg and seismic velocity structure in the South Indian Shield. Bulletin Seismological Society America, v. 90 (5), pp. 1281-1294.

Kumar, P., Yuan, X., Ravi Kumar, M., Kind, R., Li, X., and Chadha, R.K., 2007, The rapid drift of the Indian tectonic plate. Nature, v. 449, doi:10.1038/nature06214.

Kumar, P., Kind, R., Yuan, X., 2010, Receiver function summation without deconvolution. Geophysical Journal International, v. 180 (3), pp. 1223-1230.

Kumar, P., Ravi Kumar, M., Srijayanthi, G., Arora, K., Srinagesh, D., Chadha, R.K., and Sen, M.K., 2013, Imaging the lithosphereasthenosphere boundary of the Indian plate using converted wave techniques. Journal Geophysical Research: Solid Earth, v. 118, pp. 5307-5319.

Kumar, P., Sen, M.K., and Haldar, C., 2014, Estimation of shear velocity contrast from transmitted Ps amplitude variation with ray-parameter. Geophysical Journal Internationa., v. 198 (3), pp. 1431-1437.

Kumar, P., Joshi, A., Kumar, A., and Chadha, R.K., 2015, Detailed attenuation study of shear waves in the Kumaon Himalaya, India, using the inversion of strong-motion data. Bulletin Seismological Society America, v. 105, pp. 1836-1851.

Kumar, P., Joshi, A., Kumar, S., Sandeep, and Lal, S., 2018, Determination of site effect and anelastic attenuation at Kathmandu, Nepal Himalaya region and its use in estimation of source parameters of 25 April 2015 Nepal earthquake $M w=7.8$ and its aftershocks including the 12 May $2015 \mathrm{Mw}=7.3$ event. Natural Hazards, v. 91, pp. 1003-1023.

Kumar, A., Mukhopadhyay, S., Kumar, N., Baidya, P. R., 2018, Lateral variation in crustal and mantle structure in Bay of Bengal based on surface wave data. Journal of Geodynamics, v. 113, pp. 3242.

Lange, D., Tilmann, F., Henstock, T., Rietbrock, A., Natawidjaja, D., 
and Kopp, H., 2018. Structure of the central Sumatran subduction zone revealed by local earthquake travel-time tomography using an amphibious network. Solid earth, v. 9, pp. 1036-1049.

Laske, G., and Masters, G., 1997, A global digital map of sediment thickness, EOS Trans. AGU, v. 78, F483.

Lei, X., Nishizawa, O., Kusunose, K., 1993, Band-limited heterogeneous fractal structure of earthquakes and acoustic emission events. Geophysical Journal International, v. 115, pp. 79-84.

Li, Y., Wu, Q., Pan, J., Zhang, F., and Yu, D., 2013, An upper-mantle S-wave velocity model for East Asia from Rayleigh wave tomography. Earth Planetary Science Letters, v. 377-378, pp. 367377.

Liang, X., Chen, Y., Tian, X., Chen, Y.J., Ni, J., Gallegos, A., Klemperer, S.L., Wang, M., Xu, T., Sun, C., Si, S., Lan, H., Teng, J., 2016, 3D imaging of subducting and fragmenting Indian continental lithosphere beneath southern and central Tibet using body-wave finite-frequency tomography. Earth Planetary Science Letters, v. 443, pp. 162-175.

Mahadevan, T.M., and Subbarao, K.V., 1999, Seismicity of the Deccan Volcanic Province - An Evaluation of some Endogenous factors. Memoir Geological Society India, v. 43, pp. 453- 484.

Main, I.G., and Al-Kindy, F.H., 2002, Entropy, energy, and proximity to criticality in global earthquake populations. Geophysical Research Letters, v. 29, pp. 25.1-25.4.

Mallick, R., Rajendran, K., 2016, The 2014 M w 6.1 Bay of Bengal, Indian Ocean, earthquake: A possible association with the $85^{\circ} \mathrm{E}$ ridge. Bulletin Seismological Society America, v. 106, pp. 408417.

Mandal, P., Mabawonku, A.O., Dimri, V.P., 2005, Self-organized fractal seismicity of reservoir triggered earthquakes in the KoynaWarna seismic zone, western India. Pure Applied Geophysics, v.162, pp. 73-90.

Mandal, P., and Pujol, J., 2006, Seismic imaging of the aftershock zone of the $2001 \mathrm{Mw} 7.7$ Bhuj earthquake, India. Geophysical Research Letters, v. 33 (5), L05309, doi:10.1029/2005GL025275.

Mandal, P., 2009, Crustal shear-wave splitting in the epicentral zone of the $2001 \mathrm{Mw}$ 7.7 Bhuj earthquake, Gujarat, India. Journal of Geodynamics, v. 47, 246-258.

Mandal, P., and Biswas, K., 2016. Teleseismic receiver functions modeling of the eastern Indian craton. Physics Earth Planetary Interiors, v. 258, pp. 1-14.

Mandal, P., 2017, Lithospheric thinning in the Eastern Indian Craton: Evidence for lithospheric delamination below the Archean Singhbhum Craton? Tectonophysics, v. 698, pp. 91-108.

Maurya, M., Montagner, J.-P., Ravi Kumar, M., Stutzmann, E., Kiselev, S., Burgos, G., Rao, N.P., and Srinagesh, D., 2016, Imaging the lithospheric structure beneath the Indian continent. Journal Geophysical Research: Solid Earth, v. 121, doi.10.1002/ 2016JB012948.

McNamara, D.E., Owens, T.J., and Walter, W.R., 1995, Observations of regional phase propagation across the Tibetan Plateau. Journal Geophysical Research, v. 100, pp. 22215-22229.

Mishra, O.P., and Zhao, D., 2003, Crack density, saturation rate and porosity at the 2001 Bhuj, India, earthquake hypocenter: a fluiddriven earthquake? Earth Planetary Science Letters, v. 212 (3-4), pp. 393-405.

Mishra, O.P., 2013, Crustal heterogeneity in bulk velocity beneath the 2001 Bhuj earthquake source zone and its implications. Bulletin Seismological Society America, v. 103 (6), pp. 32353247.

Mitra, S., Priestley, K., Bhattacharyya, A.K., Gaur, V.K., 2005, Crustal structure and earthquake focal depths beneath northeastern India and southern Tibet. Geophysical Journal International, v. 160 (1), pp. 227-248.

Mitra, S., Priestley, K., Gaur, V.K., and Rai, S.S., 2006, Frequencydependent $\mathrm{Lg}$ attenuation in the Indian platform. Bulletin Seismological Society America, v. 96 (6), pp. 2449-2456.

Mitra, S., Priestley, K., Gaur, V.K., Rai, S.S., and Haines, J., 2006, Variation of Rayleigh wave group velocity dispersion and seismic heterogeneity of the Indian crust and uppermost mantle. Geophysical Journal International, v. 164 (1), pp. 88-98.

Mitra, S., Priestley, K., Kajaljyoti, B., and Gaur, V., 2018, Crustal structure and evolution of the eastern Himalayan plate boundary system, northeast India. Journal Geophysical Research: Solid Earth, v. 123, pp. 621-640.

Mukhopadhyay, S., Sharma, J., Massey, R., Kayal, J.R., 2008, Lapsetime dependence of coda Q in the source region of the 1999 Chamoli earthquake. Bulletin Seismological Society America, v. 98 (4), pp. 2080-2086.

Mukhopadhyay, S., Sharma, J., Del-Pezzo, E., and Kumar, N., 2010, Study of attenuation mechanism for Garwhal-Kumaun Himalayas from analysis of coda of local earthquakes. Physics Earth Planetary Interiors, v. 180 (1-2), pp. 7-15.

Naganjaneyulu, K., and Santosh, M., 2012, The nature and thickness of lithosphere beneath the Archean Dharwar Craton, southern India: a magnetotelluric model. Journal Asian Earth Sciences, v. 49, pp. 349-361.

Nath, S.K., and Dewangan, P., 2002, Detection of seismic reflections from seismic attributes through fractal analysis. Geophysical Prospecting, v. 50, pp. 341-360.

Nath, S.K., Vyas, M., Pal, I., Sengupta, P., 2005, A seismic hazard scenario in the Sikkim Himalaya from seismotectonics, spectral amplification, source parameterization, and spectral attenuation laws using strong motion seismometry. Journal Geophysical Research: Solid Earth, v. 110, B01301, doi:10.1029/ 2004 JB003199.

Negi, J.G., Agrawal, P.K., and Pandey, O.P., 1986, Super mobility of hot Indian lithosphere. Tectonophysics, v. 131, pp. 147-156.

Oreshin, S., Kiselev, S., Vinnik, L., Prakasam, K.S., Rai, S.S., Makeyeva,L., and Savvin, Y., 2008, Crust and mantle beneath western Himalaya, Ladakh and western Tibet from integrated seismic data. Earth Planetary Science Letters, v. 271 (1-4), pp. 75-87.

Padhy, S., 2005. A scattering model for seismic attenuation and its global applications. Physics Earth Planetary Interiors, v. 148 (1), pp. 1-12.

Padhy, S., and Crampin, S., 2006, High pore-fluid pressures at Bhuj, inferred from $90^{\circ}$-flips in shear- wave polarizations. Geophysical Journal International, v. 164, pp. 370-376.

Padhy, S., and Subhadra, N., 2010. Attenuation of high-frequency seismic waves in northeast India. Geophysical Journal International, v. 181, pp. 453-467.

Padhy, S., and Subhadra, N., 2010, Frequency-dependent attenuation of $\mathrm{P}$ and $\mathrm{S}$ waves in northeast India. Geophysical Journal International, v. 183, pp. 1052-1060.

Padhy, S., Subhadra, N., and Kayal, J.R., 2011, Frequency dependent body and coda waves in Andaman Sea basin, Bulletin Seismological Society America, v. 101, doi: 10.1785/0120100032.

Padhy, S., and Subhadra, N., 2013. Separation of intrinsic and scattering seismic wave attenuation in Northeast India, Geophysical Journal International, v. 195 (3), pp.1892-1903.

Padhy, S., Wegler, U., and Korn, M., 2007, Seismogram envelope Inversion using a multiple isotropic scattering model: Application to aftershocks of the 2001 Bhuj earthquake. Bulletin Seismological Society America, v. 97 (1B), pp. 222-233.

Padhy, S., Mishra, O.P., Subhadra, N., Dimri, V.P., Singh, O.P., Chakrabortty, G.K., 2015, Effects of errors and biases on the 
scaling of earthquake spatial pattern: application to the 2004 Sumatra-Andaman sequence. Natural Hazards, v. 77 (1), pp. 7596.

Parvez, I.A., Sutar, A.K., Mridula, M., Mishra, S.K., and rai, S.S., 2008, Coda Q Estimates in the Andaman Islands Using Local Earthquakes. Pure Applied Geophysics, v. 165, pp. 1861-1878.

Pavan Kumar, V., Prakasam, K.S., Rai, S.S., and Gupta, S., 2015, Upper-mantle anisotropy beneath the south Indian Shield: Influenced by ancient and recent Earth processes. Lithosphere, v. 7, pp. 108-116.

Pavan Kumar, G., Mahesh, P., Nagar, M., Mahender, E., Kumar, V., Mohan, K., and Ravi Kumar, M. 2017, Role of deep crustal fluids in the genesis of intraplate earthquakes in the Kachchh region, northwestern India. Geophysical Research Letters, v. 44 (9), pp. 4054-4063.

Priestley, K., Jackson, J., and McKenzie, D., 2008, Lithospheric structure and deep earthquakes beneath India, the Himalaya and southern Tibet. Geophysical Journal International, v. 172, pp. 345362.

Rai, S.S., Priestley, K., Suryaprakasam, K., Srinagesh, D., Gaur, V.K., Du, Z., 2003, Crustal shear velocity structure of the south Indian shield. Journal Geophysical Research: Solid Earth, v. 108 (B2), doi:10.1029/2002JB001776.

Rai, S.S., Priestley, K., Gaur, V.K., Mitra, S., Singh, M.P., and Searle, M., 2006, Configuration of the Indian Moho beneath the NW Himalaya and Ladakh. Geophysical Research Letters, v. 33 (15), https://doi.org/10. 1029/2006GL026076.

Rai, S.S., Padhi, A., Sarma, P.R., 2009, High crustal seismic attenuation in Ladakh-Karakoram. Bulletin Seismological Society America, v. 99 (1), pp. 407-415.

Rajendran, K., and Rajendra, C.P., 2011, Revisiting the earthquake sources in the Himalaya: Perspectives on past seismicity. Tectonophysics, v. 504, pp. 75-88.

Rajendran, K., Parameswaran, R. M., and Rajendran, C.P., 2017. Seismotectonic perspectives on the Himalayan arc and contiguous areas: Inferences from past and present earthquakes. Earth Science Reviews, v. 173, pp. 1-30.

Ramesh, D.S., Srinagesh, D., Rai, S.S., Prakasam, K.S., Gaur, V.K., 1993, High-velocity anomaly under the Deccan volcanic province . Physics Earth Planetary Interiors, v. 77 (3-4), pp. 285-296.

Rao, K.M., Ravi Kumar, M., Singh, A., and Rastogi, B.K., 2013, Two distinct shear wave splitting directions in the northwestern Deccan volcanic province. Journal Geophysical Research: Solid Earth, v. 118 (10), pp. 5487-5499.

Rao, B.P., and Ravi Kumar, M., 2014, Seismic evidence for slab graveyards atop the Core Mantle Boundary beneath the Indian Ocean Geoid Low. Physics Earth Planetary Interiors, v. 236, pp. 52-59.

Rao, N.P., Tiwari, V.M., Kumar, M.R., Hazarika, P., Saikia, D., Chadha, R.K., and Rao, Y.J.B., 2015, The Mw 6.9 Sikkim-Nepal earthquake of September 2011: a perspective for wrench faulting in the Himalayan thrust zone. Natural Hazards, v. 77, pp. 355366.

Raoof, J., Mukhopadhyay, S., Koulakov, I., and Kayal, J.R., 2017, 3D seismic tomography of the lithosphere and its geodynamic implications beneath the northeast India region. Tectonics, v. 36 (5), pp. 962-980.

Ramesh, D.S., Ravi Kumar, M., Uma Devi, E., Raju, P.S., Yuan, X., 2005, Moho geometry and upper mantle images of northeast India. Geophysical Research Letters, v. 32 (14), https://doi.org/10. 1029/ 2005 GL 022789.

Rapine, R., Tilmann, F., West, M., Ni, J., and Rodgers, A., 2003, Crustal structure of northern and southern Tibet from surface wave dispersion analysis. Journal of Geophysical Research: Solid Earth, v.108, https:// doi.org/10.1029/ 2001JB000445.

Raval, U., and Veeraswamy, K., 2003, India-Madagascar separation: breakup along a preexisting Ravi Kumar, M., Raju, P.S., Uma Devi, E., Saul, J., and Ramesh, D.S., 2004, Crustal structure variations in northeast India from converted phases. Geophysical Research Letters, v. 31 (17), L17605.

Ravi Kumar, M., and Singh, A., 2008, Evidence for plate motion related strain in the Indian shield from shear wave splitting measurements. Journal Geophysical Research: Solid Earth, v. 113 (B8), https://doi. org/10. 1029/ 2007JB005128.

Ravi Kumar, M., Saikia, D., Singh, A., Srinagesh, D., Baidya, P.R., Dattatrayam, R.S., 2013, Low shear velocities in the sub lithospheric mantle beneath the Indian shield? Journal Geophysical Research: Solid Earth, v. 118 (3), pp. 1142-1155.

Rodgers, A.J., and Schwartz, S.Y., 1998, Lithospheric structure of the Qiangtang Terrane, northern Tibetan Plateau, from complete regional waveform modeling: Evidence for partial melt. Journal Geophysical Research: Solid Earth, v.103, pp. 7137-7152.

Rohilla, S., Rao, N.P., Gerstoft, P., Shashidhar, D., and Satyanarayana, H.V.S., 2015, Shear-wave velocity structure of the Koyna-Warna region in western India using ambient noise correlation and surface-wave dispersion. Bulletin Seismological Society America, v. 105 , pp. 473-479.

Roy, S., and Rao, R.U.M., 2000, Heat flow in the Indian shield. Journal Geophysical Research, v. 105, pp. 25587-25604.

Roy, P.N.S., Chowdhury, S., Sarkar, P., and Mondal, S.K., 2014, Fractal study of seismicity in order to characterize the various tectonic blocks of North-east Himalaya, India. Natural Hazards, v. 77, pp. 5-18.

Roy, S.K., Srinagesh, D., Saikia, D., Singh, A., and Ravi Kumar, M., 2012, Seismic anisotropy beneath the eastern Dharwar craton, Lithosphere, v. 4 (4), pp. 259-268.

Roy, S.K., Ravi Kumar, M., Srinagesh, D., 2017, Anisotropy in subduction zones: Insights from new source side S wave splitting measurements from India. Journal Geophysical Research: Solid Earth, v. 122 (8), pp. 6454-6472.

Saikia, D., Ravi Kumar, M., Singh, A., Mohan, G., and Dattatrayam, R.S., 2010, Seismic anisotropy beneath the Indian continent from splitting of direct S waves. Journal Geophysical Research, v. 115 (B12), B12315, doi:10.1029/2009JB007009.

Saikia, U., Das, R., and Rai, S.S., 2017, Possible magmatic underplating beneath the west coast of India and adjoining Dharwar craton: Imprint from Archean crustal evolution to breakup of India and Madagascar. Earth Planetary Science Letters, v. 462, pp. 1-14.

Sarkar, D., Ravi Kumar, M., Saul, J., Kind, R., Raju, P.S., Chadha,R.K., Shukla, A.K., 2003, A receiver function perspective of the Dharwar craton (India) crustal structure. Geophysical Journal International, v. 154 (1), pp. 205-211.

Sato, H., 1995, Formulation of the multiple non-isotropic scattering process in 3-D space on the basis of energy transport theory. Geophysical Journal International, v. 121, pp. 523-531.

Sato, H., Fehler, M., and maeda, T., 2012, Seismic wave propagation and scattering in the heterogeneous Earth. 2nd edn SpringerVerlag.

Saul, J., Ravi Kumar, M., Sarkar, D., 2000, Lithospheric and upper mantle structure of the Indian shield, from teleseismic receiver functions. Geophysical Research Letters, v. 27 (16), pp. 23572360.

Sen, M.K., Biswas, R., Mandal, P., and Kumar, P., 2014, Basis pursuit receiver function. Bulletin Seismological Society America, v. 104, pp. 2673-2682.

Sengupta, P., Nath, S.K., Thingbaijam, K.K.S., and Mistri, S., 2011, Fractal analysis of major faults in India on a regional scale. Journal 
Geological Society India, v. 78, pp. 226-232.

Serpetsidaki, A., Verma, N. K., Tselentis, G. A., Martakis, N., Polychronopoulou, K., and Petrou, P., 2013, Seismotectonics of lower Assam, northeast India, using the data of a dense microseismic network. Bulletin of the Seismological Society of America, v. 103 (5), pp. 2875-2883.

Sharma, Antara, Baruah, S., Piccinini, D., Saikia, S. Kayal, J.R. Kayal, 2017, Crustal seismic anisotropy beneath Shillong plateau - Assam valley in North East India: Shear- wave splitting analysis using local earthquakes. Tectonophysics, v. 717, pp. 425-432.

Shashidhar, D., Rao, N.P., Gupta, H. K., 2011. Waveform inversion of broadband data of local earthquakes in Koyna-Warna region, western India. Geophysical Journal International, 185, 292-304.

Shashidhar, D., Satyanarayana, H.V.S., Mahato, C.R., Mallika, K., 2016, Borehole seismic network at Koyna, India . Seismological Research Letters, v. 87 (3), pp. 661-667.

Shapiro, N.M., and Campillo, M., 2004, Emergence of broadband Rayleigh waves from correlations of the ambient seismic noise. Geophysical Research Letters, v. 31 (7), https://doi.org/10.1029/ 2004GL019491.

Shapiro, N.M., Campillo, M., Stehly, L., and Ritzwoller, M.H., 2005, High-resolution surface-wave tomography from ambient seismic noise. Science, v. 307, pp. 1615-1618.

Singh, S. K., Ordaz, M., Dattatrayam, R.S., and Gupta, H.K., 1999, A spectral analysis of the May 21, 1997, Jabalpur, India earthquake (Mw 5.8) and estimation of ground motion from future earthquakes in the Indian shield region. Bulletin Seismological Society America. V. 89, pp. 1620-1630.

Singh, S.K., Garcia, D., Pacheco, J.F., Valenzuela, R., Bansal, B.K., and Dattatrayam, R.S., 2004, Q of the Indian shield. Bulletin Seismological Society America, v. 94, pp. 1564-1570.

Singh, A, Ravi Kumar, M., Raju, P.S., Ramesh, D.S., 2006, Shear wave anisotropy of the northeast Indian lithosphere. Geophysical Research Letters, v. 33 (16), https://doi.org/10.1029/ 2006 GL026106.

Singh, A., Ravi Kumar, M., Raju, P.S., 2007, Mantle deformation in Sikkim and adjoining Himalaya: Evidences for a complex flow pattern. Physics Earth Planetary Interiors, v. 164 (3-4), pp. 232241.

Singh, C., Bhattacharya, P.M., Chadha, R.K., 2008, Seismicity in the Koyna-Warna reservoir site in western India: fractal and b-value mapping. Bulletin Seismological Society America, v. 98 (1), pp. 476-482.

Singh, A., and Ravi Kumar, M., 2009, Seismic signatures of detached lithospheric fragments in the mantle beneath eastern Himalaya and southern Tibet. Earth and Planetary Science Letters, v. 288 (1-2), pp. 279-290.

Singh, A.P., Rai, A., and Rai, S.S., 2011, Ambient Noise Tomography of the Central India. Int. J. Computer Science and Engineering, v. 3, pp. 2068-2074.

Singh, A., Singh, C. and Kennett, B.L.N. 2015a, A review of crust and upper mantle structure beneath the Indian subcontinent. Tectonophysics, v. 644-645, pp. 1-21.

Singh, C., Mondal, P., Singh, S., Mohanty, D., Jaiswal, N., Ravi Kumar, M., 2015b, Lg attenuation tomographic models of Himalaya and southern Tibet. Tectonophysics, v. 664, pp. 176181.

Singh, S., Singh, C., Biswas, R., Mukhopadhyay, S., and Sahu, H., 2016, Attenuation characteristics in eastern Himalaya and southern Tibetan Plateau: An understanding of the physical state of the medium. Physics Earth Planetary Interiors, v. 257, pp. 48-56.

Singh, A.P., Rao, N.P, Ravi Kumar, M., Hsieh, M. C., and Zhao, L. 2017. Role of the Kopili Fault in deformation tectonics of the Indo-Burmese Arc inferred from the rupture process of the 3
January 2016 Mw 6.7 Imphal earthquake, Bulletin Seismological Society America, doi: 10.1785/0120160276.

Snieder, R., 2004, Extracting the Green's function from the correlation of coda waves: A derivation based on stationary phase. Physics. Review, v. 69, 046610.

Snieder, R., and Wapenaar, K., 2010, Imaging with ambient noise. Physics Today, v. 63(9), pp. 44-49.

Srinagesh, D., Rai, S.S., Ramesh, D.S., Gaur, V.K., Rao, C.V.R., 1989, Evidence for thick continental roots beneath South Indian Shield. Geophysical Research Letters, v. 16 (9), pp. 1055-1058.

Subhadra, N, Padhy, S., Dimri, V.P., 2018a, Characterizing spatial heterogeneity based on the b- value and fractal analyses of the 2015 Nepal earthquake sequence. Tectonophysics, v. 722, pp. 154- 162.

Subhadra, N., Padhy, S., Tiwari, R.K., and Satyanarayana, H.V.S., 2018b, Fractal, b-value, and static stress analyses of the seismicity in western India: Implications for seismogenesis and triggering mechanism of the 2001 Bhuj aftershocks. Tectonophysics (Under review).

Sunmonu, L.A., and Dimri, V.P., 2000, Fractal geometry of faults and seismicity of Koyna-Warna region west India using LANDSAT images. Pure and Applied Geophysics, v. 157, pp. 1393- 1405.

Telesca, L., 2011, Investigating the temporal variations of the timeclustering behavior of the Koyna- Warna (India) reservoirtriggered seismicity. Chaos, Solitons and Fractals, v. 44, pp. 108113.

Tilmann, F., Ni, J., INDEPTH III Seismic Team, 2003, Seismic imaging of the downwelling Indian lithosphere beneath central Tibet. Science, v. 300, pp. 1424-1427.

Tripathi, J.N., Singh, P., and Sharma, M.L., 2014, Attenuation of high-frequency P and S waves in Garhwal Himalaya, India. Tectonophysics, v. 636, pp. 216-227.

Ugalde, A., Carcolé, E., Tripathi, J,N., 2006, Spatial distribution of scatterers in the crust by inversion analysis of coda envelopes: a case study of Gauribidanur seismic array (Southern India) Geophysical Journal International, v. 166 (2), pp. 782-794.

Ugalde, A., Tripathi, J.N., Hoshiba M., and rastogi, B.K., 2007, Intrinsic and scattering attenuation in western India from aftershocks of the 26 January, 2001 Kachchh earthquake. Tectonophysics, v. 429, pp. 111-123.

Zhao, D., Huang, Z., Umino, N., Hasegawa, A., and Kanamori, H., 2011. Structural heterogeneity in the megathrust zone and mechanism of the 2011 Tohoku-oki earthquake (Mw 9.0). Geophys. Res. Lett., v. 38, pp. L17308 


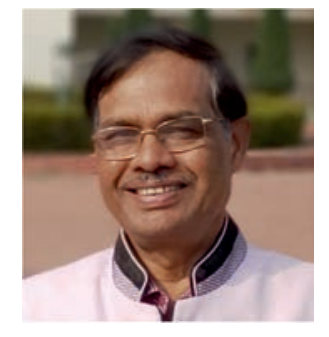

Prof. J.R. Kayal, former Deputy Director General (Head, Geophysics), Geological Survey of India (GSI), Kolkata,an Emeritus Scientist (under CSIR fellowship), Jadavpur University, Kolkata, Adjunct Professor, Indian Institute of Technology (IIT), Kharagpur, IIT-Indian School of Mines (ISM), Dhanbad, Tezpur University, Assam, Institute of Seismological Research (ISR), Gandhinagar,National Institute of Technology (NIT), Agartala and visiting professor/scientific advisor in several institutes/universities in India and abroad.He led several national and international projects on earthquake seismology.He has some 130 research publications in SCI journals, author of a book on Microearthquake Seismology (Springer, 2008) and Co-editor of some four Books on Geosciences. He did his M.Sc. Applied Geophysics in 1969 from the IIT-ISM, and PhD from the Victoria University of Wellington,New Zealand on a Commonwealth Scholarship (1979-83). He has beenawarded National Geoscience Award (1994) by the Government of India and 'Fellow' by several scientific societies in India and abroad.

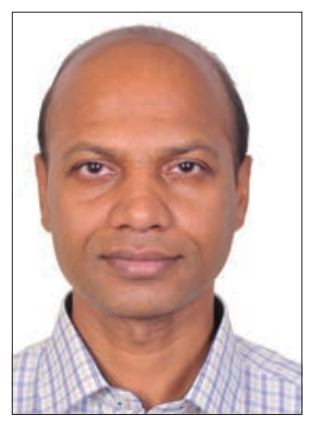

Dr Simanchal Padhy graduated in Applied Geophysics (MSc Tech) from the IIT-ISM, Dhanbad in 1998 and PhD from the Osmania University, Hyderabad in 2005. Since then he is a research scientist at the CSIR-National Geophysical Research Institute (NGRI), Hyderabad, India. He did his post-doctoral research in the University of Tokyo, Japan during 2010-12. He works mainly on propagation and scattering of high frequency seismic waves in Earth to understand nature of small-scale medium heterogeneities. 